NBER WORKING PAPER SERIES

\title{
U.S. FOREIGN-EXCHANGE-MARKET INTERVENTION DURING THE VOLCKER-GREENSPAN ERA
}

Michael D. Bordo

Owen F. Humpage

Anna J. Schwartz

Working Paper 16345

http://www.nber.org/papers/w16345

\author{
NATIONAL BUREAU OF ECONOMIC RESEARCH \\ 1050 Massachusetts Avenue \\ Cambridge, MA 02138 \\ September 2010
}

Michael Bordo is at Rutgers University (bordo@fas-econ.rutgers.edu); Owen Humpage is at the Federal Reserve Bank of Cleveland (owen.f.humpage@ @lev.frb.org), and Anna J. Schwartz is at the National Bureau of Economic Research (aschwartz@gc.cuny.edu). The authors thank Caroline Herrell, Michael Shenk, and Zebo Zakir for their research assistance. The views expressed herein are those of the authors and do not necessarily reflect the views of the National Bureau of Economic Research.

NBER working papers are circulated for discussion and comment purposes. They have not been peerreviewed or been subject to the review by the NBER Board of Directors that accompanies official NBER publications.

(C) 2010 by Michael D. Bordo, Owen F. Humpage, and Anna J. Schwartz. All rights reserved. Short sections of text, not to exceed two paragraphs, may be quoted without explicit permission provided that full credit, including $\odot$ notice, is given to the source. 
U.S. Foreign-Exchange-Market Intervention during the Volcker-Greenspan Era

Michael D. Bordo, Owen F. Humpage, and Anna J. Schwartz

NBER Working Paper No. 16345

September 2010

JEL No. F3,N1,N2

\begin{abstract}
$\underline{\text { ABSTRACT }}$
The Federal Reserve abandoned foreign-exchange-market intervention because it conflicted with the System's commitment to price stability. By the early 1980s, economists generally concluded that, absent a portfolio-balance channel, sterilized foreign-exchange-market intervention did not provide central banks with a mechanism for systematically influencing exchange rates independent of their monetary policies. If intervention were to have anything other than a fleeting, hit-or-miss, effect on exchange rates, monetary policy had to support it. Exchange rates, however, often responded to U.S. monetary-policy initiatives, so intervention to offset or reverse those exchange-rate responses can seem a contrary policy move and can create uncertainty about the strength of the System's commitment to price stability. That the U.S. Treasury maintained primary responsibility for foreign-exchange intervention only compounded this uncertainty. In addition, many FOMC participants feared that swap drawings and warehousing could contravene the Congressional appropriations process and, therefore, potentially pose a threat to System independence, a necessary condition for monetary-policy credibility.
\end{abstract}

Michael D. Bordo

Department of Economics

Rutgers University

New Jersey Hall

75 Hamilton Street

New Brunswick, NJ 08901

and NBER

bordo@econ.rutgers.edu

Owen F. Humpage

Federal Reserve Bank of Cleveland

P.O. Box 6387

Cleveland, OH 44101-1387

owen.f.humpage@clev.frb.org
Anna J. Schwartz

NBER

365 Fifth Ave, 5th Floor

New York, NY 10016-4309

aschwartz@gc.cuny.edu 


\title{
U.S. Foreign-Exchange-Market Intervention during the Volcker-Greenspan Era
}

\author{
"I think I have been around too long to be able to give you a precise definition of \\ what is a disorderly market. ... Disorder to some extent is in the eyes of the \\ beholder."
}

Edwin Truman, Director BOG's International Division, 15 November 1994

"I think intervention undermines the credibility of monetary policy by introducing some confusion as to what our fundamental objectives are as between domestic price stability and exchange rate objectives at particular points in time. ... I think some foreign exchange operations could over time undermine public support for the Fed's financial independence, which is the ultimate foundation for our credibility."

\section{J. Alfred Broaddus, President of the Federal Reserve Bank of Richmond,} 2-3 July 1996

\section{Introduction}

After 6 October 1979, through both the Volcker and Greenspan chairmanships, the Federal Reserve System underwent a long — sometimes tentative-process of rebuilding its credibility. The FOMC came to focus on an inflation objective, acknowledging an inevitable connection between achieving low, stable inflation expectations and maintaining the nation's maximum sustainable economic growth rate. Over these years, economists increasingly recognized the crucial link between central-bank independence and the integrity of monetary policy.

At the same time, the Federal Reserve underwent a similar learning process with respect to foreign-exchange operations, initially concluding that sterilized intervention was largely ineffectual but eventually deciding that intervention - even sterilized intervention - could create uncertainty about monetary policy. Between 1981 and 1985, the United States adopted a minimalist approach to intervention, but eventually reversed course under pressure from foreign governments, U.S. politicians, and some influential economists who continued to view floating exchange rates as excessively volatile, vulnerable to destabilizing speculation, and prone to serious departures from their fundamentals. In 1985, the Treasury again adopted an activist approach. The sterilized interventions that followed the Plaza and Louvre accords, at best, fared no better than earlier operations. The movement in dollar exchange rates during these episodes seems to reflect changes in monetary policy, not intervention. At most, intervention gave the impression of international cooperation and U.S. concern about dollar exchange rates, but the Federal Reserve came to view that impression as very costly.

As attitudes about the proper role of monetary policy changed, monetary economists increasingly found intervention inconsistent with anchoring inflation expectations. The Federal Reserve's response to the 19 October 1987 stock-market collapse first highlighted the potential for conflict between monetary policy and intervention, but the problem became critical in 1989 . At that time, the FOMC was tightening, trying to stem a rise in inflation and to consolidate longfought gains in its credibility, but the Foreign Exchange Desk, under strong pressure from the U.S. Treasury, was buying huge amounts of German marks and Japanese yen and warehousing large positions for the Treasury. At the 3 October 1989 FOMC meeting, opponents of 
intervention went beyond perennial doubts about the efficacy of intervention and argued forcefully that intervention created uncertainty about the objectives of monetary policy. A central bank cannot credibly anchor inflation expectations and attempt to manage exchange rates, particularly when the fiscal authority has primary responsibility for the latter. Thereafter, the Federal Reserve began to back away from foreign-exchange intervention, and since 1995, except for one operation against Japanese yen in 1998 and one operation against the euro in 2000, the United States has stopped intervening.

\section{Before Plaza: 1981 - 1985}

Soon after the Reagan administration formally inaugurated its minimalist intervention strategy, the dollar started a sustained, broad-based, appreciation on both a nominal and real basis. ${ }^{1}$ During this time, a tightening in U.S. monetary policy, in conjunction with expanding federal budget deficits, raised real interest rates in the United States and attracted substantial inflows of foreign funds. While these financial inflows mitigated the traditional, interestsensitive crowding out that economists expected from the emerging U.S. policy mix, the resulting real dollar appreciation opened U.S. manufacturers to intense foreign competition. Confronted with mounting protectionist threats and faced with the criticism of those policymakers and academics who still regarded intervention, particularly U.S. intervention, as necessary to maintain orderly market conditions, the administration eased back into an activist's intervention role in early 1985, despite evidence that intervention did not offer an independent tool for affecting exchange rates (see figures 1 and 2).

\section{Dollar Appreciation}

Between July 1980 and March 1985, the U.S. dollar appreciated nearly 55 percent on a nominal trade-weighted basis relative to the currencies of the other major developed countries. Over this same time period, the dollar appreciated 89 percent relative to the German mark, the United States' key intervention currency and the linchpin of the European Exchange-Rate Mechanism. Movements against the Japanese yen, which emerged as a second key U.S. intervention currency around this time, were more muted. Between July 1980 and March 1985, the dollar appreciated only 17 percent against the yen. Most of the dollar's appreciation was on a real basis, suggesting a significant deterioration in the competitive position of the U.S. tradedgoods sector. On a trade-weighted real basis, the dollar appreciated nearly 49 percent between mid-1980 and early 1985 .

A tightening of U.S. monetary policy prompted the dollar's appreciation. The Federal Reserve had initially moved to tighten monetary policy and to eliminate inflation after Paul Volcker became chairman in August 1979. ${ }^{2}$ At a secret meeting on 6 October 1979, the FOMC adopted new operating procedures that attempted to improve the System's credibility with respect to its monetary targets by focusing on a reserve aggregate as an operating target rather than on the federal funds rate (see Hetzel 2008, pp. 166-169). ${ }^{3}$ The Federal Reserve also raised marginal reserve requirements and at the Carter administration's request, imposed credit controls (Schreft 1990). The economy slipped into recession by January 1980.

The Committee's initial policy steps towards eliminating inflation proved tentative. During the recession of 1980, for example, the System, now under its new operating procedure, allowed the federal funds rate to fall sharply, resulting in a negative real federal funds rate in mid-1980 (see figures 3 and 4). After the Board removed credit controls in July 1980, economic activity improved, but high long-term bond rates suggested no improvement in inflation 
expectations. The Federal Reserve tightened again in 1981 and generally maintained that stance despite a serious recession that began in middle of the year and continued through almost all of 1982. In mid-1982, the Committee again allowed nominal policy rates to ease somewhat. In part, this was a response to the continuing recession and to a continuing moderation of inflation, but an emerging developing country debt crisis also may have contributed to the policy change. ${ }^{4}$

Although the federal funds rate generally fell during this pre-Plaza period, the decline conformed to the Taylor principle. As the economy recovered after the 1982 recession, Volcker acted to prevent a rise in inflation expectations by keeping the funds rate high and by responding to increases in long-term bond rates (Hetzel 2008, pp. 172-179). The real federal funds rate fluctuated around 5.2 percent between 1981 and 1985, which was high by historical standards.

Against the backdrop of tight monetary policy, the Reagan administration entered the White House in January 1981, instituting substantial cuts in personal income taxes and increases in military expenditures. The Reagan administration also hoped for cuts in non-defense federal spending, but Congress was unwilling to enact these. ${ }^{5}$ Consequently, the federal-budget deficit increased from $2 \frac{1}{2}$ percent of GDP in FY1981 to 4 percent of GDP in FY1982 and to 6 percent of GDP in FY1983. The federal-budget deficit then remained near 5 percent of GDP over the next three fiscal years.

By 1982, the tight-money-loose-fiscal policy mix had pushed nominal interest rates in the United States above those in the other major developed countries, even though many countries tried to resist the resulting downward pressures on their own currencies by tightening monetary policy, often through non-sterilized interventions (BIS 1983, pp. 67-68) (see figure 5). In addition, the economic recovery from the 1981-82 recession occurred sooner, and remained subsequently stronger, in the United States than in most European countries. The improved business outlook, more favorable business taxes, and lower expected inflation improved the real return on capital in the United States. These conditions attracted foreign funds into dollardenominated assets. ${ }^{6}$

During any period of tight monetary policy and strong economic growth, such an expansion of the federal budget deficit might have crowded out private investment and other interest-sensitive economic activity. Yet, in the early 1980s, traditional crowding out did not take place. Fixed investment in the United States fell as a percentage of GDP in 1982, but thereafter increased and was higher in 1984 and 1985 than in 1981 or in the late 1970s. Strong foreign financial inflows and the dollar's appreciation shifted fiscal crowding out from interestsensitive sectors of the economy to the traded-goods sector.

Prior to 1985 , few in the administration worried about the impact of the strong dollar on the traded-goods sector. They seemed to view crowding out in this sector as better than the traditional variety. The Council of Economic Advisors (1984, pp. 55-57) suggested that the investment sector contributed more to potential economic growth than the traded goods sector and that higher potential growth eased inflationary pressures.

The administration actually took steps to encourage foreign financial inflows in the years prior to the Plaza Accord. The Treasury pressured foreign governments, notably Japan, to liberalize their financial markets, giving the United States greater access to borrowed funds. In 1984, the administration eliminated the withholding tax on interest payments to foreigners who invested in U.S. corporate and government bonds. The Treasury also allowed U.S. corporations 
to issue bearer bonds to foreigners and designed new U.S. government bonds to be more attractive to foreigners.

Treasury Secretary Regan interpreted the dollar's appreciation as an international vote of confidence in the administration's policies (Feldstein 1994, p. 70; Volcker and Gyohten, 1992, p. 179) and was unwilling to amend the minimalist intervention strategy that Under Secretary of the Treasury for Monetary Affairs, Beryl Sprinkel, had introduced in early 1981. ${ }^{7}$ As the dollar appreciated, however, foreign central banks - notably Germany-intervened heavily and generally tightened monetary policy in attempts to limit their currencies' depreciations. They complained about the U.S. policy mix and urged intervention (Destler and Henning 1989, p. 23). Foreign central banks, particularly the French, continued to believe that intervention was effective. They maintained that exchange rates frequently deviated from fundamentals and that excessive exchange-rate volatility was detrimental both to domestic economic activity and to the international adjustment process. They continued to believe, as they did back in 1973, that U.S. intervention, in particular, had an important "psychological" effect on the market (see FOMC Minutes 29-30 March 1982, p. 4).

Perhaps to mollify foreign criticism of its minimalist approach, at the Versailles Economic Summit on 4-6 June 1982, the United States agreed to a French proposal for a study of the G7's experience with intervention since the inception of generalized floating. In March 1983, the Working Group on Exchange Market Intervention released their findings, generally known as the Jurgensen Report after its chairman (Jurgensen 1983).

\section{The Jurgensen Report and Emerging Research}

With a decade of observations, the Jurgensen Report was the first official study of intervention. It confirmed that many $\mathrm{G} 7$ participants still had a wary attitude about freely floating exchange rates. They saw the market as inefficient, prone to disorder, and capable of serious deviations from fundamentals, by which they often meant current-account balances and inflation differentials.

As a treatise on intervention, however, the Jurgensen Report fell far short. The report, itself, failed to clearly address and answer the most critical question: Did intervention enable central banks to systematically pursue an exchange-rate objective independent of their other monetary-policy goals? Its narrative often failed to carefully distinguish between sterilized intervention and unsterilized intervention or to isolate intervention from other policy actions. As a result, while the conclusions may have tempered people's beliefs about the effectiveness (or ineffectiveness) of intervention, they could dispel neither an activist's, nor a non-activist's position. The imprecision seemed, and probably was, intentional. To its credit, the Jurgensen Report did initiate some serious background studies of intervention, which addressed the critical issues more directly, and it opened the door for further academic work (see Henderson and Sampson 1983).

The Jurgensen report found that intervention — presumably both the unsterilized and sterilized varieties - had been an effective tool for influencing exchange rates in the short run. The report claimed that unsterilized intervention was more effective than sterilized intervention, but it failed to discuss the potential conflict with domestic monetary-policy objectives that unsterilized intervention could create. The report also indicated that in the face of persistent market pressures, sterilized intervention was ineffective and that "supportive" domestic monetary-policy changes were necessary. ${ }^{8}$ But, why then undertake sterilized intervention? 
Was it not redundant to normal open-market operations? Many participants asserted that sterilized intervention could reinforce the exchange-rate consequences of monetary-policy changes, but the Report offered no support for this important contention. Bonser-Neal et al. (1998) would eventually refute this claim. If, on the other hand, domestic policies were inconsistent with exchange-rate objectives, sterilized intervention was, at best, useless. The Jurgensen Report gave a qualified nod to coordinated interventions over unilateral actions and eschewed capital controls, which many countries still maintained in their arsenals of exchangerate policies (see: Jurgensen 1983, pp. 17-21; see also Henderson and Sampson 1983, pp. 830833).

At about the time of the Jurgensen Report, academic attitudes about foreign-exchange intervention were undergoing an important change. The dominant paradigm for investigating sterilized intervention was still the portfolio-balance approach. Definitions still described sterilized intervention as a change in the currency composition of outstanding interest-bearing government debt that left the monetary base unchanged (see Jurgensen 1983, p. 6; Rogoff 1984, p. 133; Loopesko 1984). Adams and Henderson (1983, p. 3), for example, noted the difficulty in measuring and testing intervention: "Many other actions of the financial authorities affect the currency composition of net official assets in ways essentially indistinguishable from the effects of the traditional proxies [for intervention]." 9 This, of course, is all correct, but the emphasis on asset composition is only relevant if intervention works through a portfolio-balance channel. Today, by contrast, researchers define sterilized intervention as not affecting the monetary base. They refer to changes in asset compositions as the method of achieving sterilization, not as the defining characteristic of sterilized intervention.

Despite the portfolio-balance approach's predominance and evidence of a time-varying risk premium, the emerging empirical evidence offered little support for an exploitable portfoliobalance channel. ${ }^{10}$ As Obstefeld and Rogoff (1997, p. 594) later concluded, "a large body of empirical research finds very little evidence of a portfolio-balance effect on foreign exchange risk premiums. ... Global government debt levels simply change too slowly and predictably... to explain the size and the volatility of the exchange rate risk premium." The early work — prior to the Jurgensen Report - on the portfolio-balance effect did not directly include intervention data, which monetary authorities still kept confidential, but given the definition of sterilized intervention, this work's conclusions were germane to any assessment of intervention's effectiveness. Hutchison's (1984) investigation of Japanese intervention is a good example, and his conclusions are about as charitable to a portfolio-balance effect as anyone at the time had offered. Hutchison, while not completely rejecting a portfolio-balance mechanism, concluded that Japanese intervention would need to be massive to affect the yen-dollar exchange rate through this channel.

While the portfolio-balance framework was still dominant, a signaling channel had emerged (Mussa 1981, Genberg 1981). Most researchers in the early 1980s interpreted signaling as providing information and affecting private expectation predominately - if not only — about future monetary policies (Rogoff 1984, p. 133. Solomon 1983, pp. 10-11). This narrow view of signaling seems odd because the Desk had often referred to the "psychological" effects of intervention. Presumably this meant that when traders were misinformed about fundamentals, defined more broadly than merely future monetary policies, intervention could guide them.

With the Jurgensen Report, studies began to emerge that used official confidential data to consider the effects of intervention on exchange rates. ${ }^{11}$ This evidence offered mixed support for 
intervention. Loopesko (1984) - the most influential paper associated with the Jurgensen Report - found that in most of her tests, cumulative sterilized intervention affected unexploited profits from a covered-interest-parity condition through either a portfolio-balance effect or a signaling channel. Moreover, she found support explicitly for the portfolio-balance model in about one-half of currencies pairs that she considered. She did not, however, report coefficients, which in previous work had often proved wrong-signed in portfolio models. Rogoff (1984), in contrast, found no evidence that Canadian intervention operated through a portfolio-balance channel. Humpage (1984) using time-series techniques and focusing on exchange rates - instead of unexploited profits - found that the heavy U.S. intervention in 1978 and 1979 had no obvious effect on daily exchange-rate movements. Micossi and Rebecchini (1984), in contrast, found some evidence that official Italian intervention affected the lira.

While inconclusive, the weight of the evidence did not rule out sterilized intervention, but it appeared to shift against a portfolio-balance channel and towards a narrowly defined signaling channel; that is, intervention as a signal of future monetary-policy changes. If intervention operated through a signaling mechanism, however, it was not completely independent of monetary policy, which economists at the time understood. To keep the signal credible, monetary policy would have to eventually respond in the appropriate manner. Moreover, for narrowly interpreted signaling to work, monetary authorities should not undertake intervention secretively, as U.S. monetary authorities heretofore often did (see Genberg 1981, pp. 6-8). The amount of an intervention did not seem to matter much for a signaling mechanism, while infrequent, coordinated operations might heighten the signal. If, on the other hand, intervention might still work through a portfolio-balance mechanism, the operations should be massive and possibly secretive, since coordination only mattered if it increased the size of an intervention.

Pressure, Politics, and Monetary Policy

Academic studies, however, never had much of an impact on intervention policy. By 1983 and 1984, calls for U.S. intervention were widespread and growing. In addition to many G7 countries, Federal Reserve officials, notably Chairman Paul Volcker and Federal Reserve Bank of New York President Anthony Solomon, pressed the Treasury to undertake intervention during the years of the dollar's appreciation. Volcker feared that the prolonged real dollar appreciation, even though it tended to lower the relative dollar-price of traded goods, might actually undermine the System's anti-inflation policies. He observed that the real dollar appreciation was having serious structural affects on U.S. manufactures by eroding their competitiveness. He worried that if business activity began to slow, the System would come under heavy administration and Congressional pressures to back away from its tough monetarypolicy stance and to offset the dollar's appreciation through lower interest rates. He did not want monetary policy to pursue an exchange-rate objective at the expense of an inflation goal (see: Volcker and Gyohten 1992, pp. 179-80, Destler and Henning 1989, pp. 30-31). Sterilized intervention could at least buy him some cover.

As early as March 1983, Solomon wanted to approach the Treasury about automatically intervening when the dollar moved "quickly" (that is, disorderly), and he complained that intervention opportunities were routinely lost because the Treasury typically hesitated (FOMC Transcripts 28-29 March 1983, p. 18). Later, out of frustration with the minimalist approach, he suggested that the small amounts of funds devoted to intervention stemmed from the Treasury's desire to discredit the operations entirely (FOMC Transcripts 19-20 December 1983, p. 52). 
While Paul Volcker's argument for intervention in 1984 did not stem from a fear that the U.S. current-account position was unsustainable, by that time others within the System held such a view (Bulletin September 1984, p. 694). At some point, they feared, foreign investors would become reluctant to hold additional dollar-denominated assets in their portfolios without compensation for the risks of doing so. The dollar's appreciation prolonged and worsened the problem. When the inevitable portfolio adjustment took place, the dollar could come under intense downward pressure.

After the Treasury continually rebuffed Federal Reserve suggestions for a more active intervention policy, Volcker briefly considered, but rejected, intervening without the Treasury's participation. He feared that asserting the Federal Reserve's independent authority for intervention would create political problems for the System and dissention within the FOMC, particularly given the lingering doubts about the efficacy of intervention (Volcker and Gyohten 1992, pp. 180-18). Emblematic of the difference of opinion about intervention within the FOMC at the time was the following exchange: During a discussion of intervention, Governor Roberts asked if the Desk knew better than the market where the dollar should be. Chairman Volcker responded, "At times;" Governor Wallich stated, "Yes;" but Governor Partee quipped, "I doubt it." (FOMC Transcripts 28-29 March 1983, p. 18)

By mid-1983, the manufacturing sector was starting to pressure the administration and Congress for relief from the competitive effects of the strong dollar. Between 1981 and 1985, their petitions for trade policy almost doubled from the late-1970s average and seemed to follow the business-cycle conditions and the dollar's appreciation (Richardson, 1994, pp. 636-37).

Manufacturers directed their ire particularly against Japan. Increasingly, manufactures blamed persistent U.S. trade deficits with Japan on unfair Japanese trading practices, such as dumping, limiting market access, and industrial policies. U.S. manufactures saw domestic trade restrictions as justified retaliation.

When complaints about the dollar's appreciation fell on deaf ears within the administration, Congress began to apply leverage by introducing a wide range of protectionist legislation. In October 1984, the administration attempted to head-off complaints about the strong dollar and widening trade deficits by reaching an agreement with Japan to remove capital controls and the, so-called, administrative guidance that discouraged foreign financial flows into Japan. Stronger financial flows from the United States to Japan would encourage a yen appreciation vis a vis the dollar and, presumably, improve the United States' competitive position. These efforts had little effect, and by 1985, prior to the Plaza Accord, Congress generated "a veritable explosion of trade legislation" (Destler and Henning 1989, p. 39).

Adding to the mix of pressures on the administration and the System, some academic economists began to contend that the dollar's appreciation in late 1984 and early 1985 was inconsistent with market fundaments and started to question the allocative efficacy of floating exchange rates (Frankel 1994, p. 301). To be sure, Meese and Rogoff (1981, 1982, 1983) had already cast serious doubt on the profession's ability to accurately describe equilibrium exchange rates. Still, many economists maintained that exchange rates ultimately must respond to relative inflation differentials or current-account imbalances. Dornbusch (1976) had demonstrated that exchange rates could overshoot a purchasing-power-parity equilibrium, and many economists understood that trading rules generated profits, suggesting that exchange markets were not perfectly efficient. To these economists, the dollar was clearly overshooting its equilibrium, 
implying that any resulting changes in output, prices, or trading patterns were temporary, reversible, and a misallocation of resources. ${ }^{12}$ They called for a policy response. ${ }^{13}$

If the monetary authorities would not respond, Congress would. Just prior to August 1985, Senators Bradley, Moynihan, and Baucus submitted legislation that would require the Treasury and the System to intervene in the foreign-exchange market in specific amounts when the United States ran a large current-account deficit (Destler and Henning 1989, pp. 36-39). ${ }^{14}$

\section{Ending the Minimalist Strategy}

In late 1984, the Federal Reserve began to lower its policy rates, but the System's actions remained limited until early 1986. Real rates remained relatively high throughout 1985 (see figures 5 and 6). Initially foreign countries - notably Germany and Japan-were reluctant to cut interest rates, but they eventually followed suit. By mid-1984, interest-rate spreads that favored the dollar began to narrow, suggesting a dollar depreciation. These cautious and limited monetary-policy changes set an important guiding tone for the dollar over the subsequent two years.

On 17 January 1985, the G5 met in Washington. Treasury Secretary Regan announced that the G5 countries had reaffirmed their commitment to macroeconomic convergence, but the G5's recent discussions focused more on exchange markets than in the past, and they "reaffirmed" their 1983 Williamsburg Summit commitment to concerted intervention and agreed to sell dollars. The heavier emphasis on intervention evolved because the large industrial countries resented tightening their domestic monetary policies as a counterweight to the dollar's strength. (They seem to have already forgotten the conclusions reached in the Jurgensen Report.) Their recent economic recovery had been sluggish. Any intervention would be undertaken when all parties to an operation agreed, and it would be concerted with each central bank acting in its own market. ${ }^{15}$

The objective of the intervention was a lower dollar, but — as Chairman Volcker indicated - the United States was not undertaking "drive-the-dollar-down operations." (FOMC Transcripts 18 January 1985, p. 5) Consistent with Volcker's characterization, U.S. operations remained fairly limited. Between 22 January 1985 and 1 March 1985, the United States only bought German marks on eight days (see table 1). The transactions ranged from $\$ 46$ million equivalent in January to $\$ 100$ million by the end of February. The System also bought $\$ 48$ million equivalent Japanese yen on 1 February 1985. The Bundesbank and other monetary authorities also intervened. Germany intervened more frequently than the United States (28 days), and typically on a much larger scale.

During this period, the United States intervened primarily in German marks because of its importance within the European Monetary System. By buying and selling German marks, the United States could, potentially, affect the relationship of the dollar vis-à-vis all European currencies. In addition, the United States intervened in Japanese yen because that currency was quickly acquiring international status (see FOMC Transcripts 18 January 1985, p. 4). Typically in G5 communiqués the United States mentioned a willingness to intervene in G5 currencies, and the United States continued to maintain the system of swap lines that it established in the 1960s to finance interventions, but after 1980 the United States never intervened in any other currency besides the mark and yen-with one exception. 
The United States undertook an unusual intervention in British pounds in February 1985 for political reasons. At the time, sterling was under strong downward pressure, and Prime Minister Thatcher was scheduled to visit the United States. The United States bought $\$ 16.4$ million worth of British pounds, split between the System's and the U.S. Treasury's accounts, sometime in February. ${ }^{16}$ When Governor Rice questioned the political nature of this intervention, Sam Cross responded (FOMC Transcripts 26 March 1985, p. 3): "Well, I think it had some implication of being done in light of those political circumstances, yes."

Economically, this transaction was inconsequential, but it highlighted an important problem that intervention always posed for central-bank independence when the political authorities had some control over the operations. Consistent with fears expressed by the FOMC in the early 1960s, by undertaking this intervention, the System seemed to act as a foreign-policy appendage of the State Department and outside of the appropriations process (see chapter 3).

The dollar peaked in late February 1985 and, thereafter, generally depreciated throughout the next three years. In late August and early September 1985, however, it seemed like the depreciation had stalled. At this time, the dollar began to appreciate as market participants temporarily lowered their expectations for further interest-rate cuts in the United States. Economic activity seemed robust, money growth was strong, and foreign investors were not rebalancing their portfolios away from U.S. securities as some had feared (Bulletin February 1986, 109-110).

\section{An Analysis of Pre-Plaza Interventions}

The Regan-Sprinkel minimalist approach did not entirely preclude foreign-exchange intervention (see figures 1 and 2 and table 1). Under this regime, the United States intervened "only when necessary to counter conditions of clear and manifest disorder in exchange markets." (Desk Report, March 1982, p. 2) "Clear" and "manifest" seemed to be the new operative words. Between 20 April 1981 and 29 March 1985, a period consisting of 1030 business days, the United States intervened on 25 occasions against German marks. On 8 of these occasions, the Desk also bought Japanese yen. The Desk bought only yen on 3 days. As can be seen it table 1, the frequency of these transactions grew as the dollar continued to appreciate relative to the German mark. Most transactions were split equally between the Treasury's and the System's accounts.

Although the number of interventions during this pre-Plaza period is too small to draw strong conclusions, our analysis, which we explained in the empirical appendix, suggests that although U.S. purchases of marks and yen did not foster dollar depreciations, they did seem to moderate the pace of the dollar's appreciation. Only 6 of the 24 U.S. purchases of German marks were associated with a same-day dollar depreciation against the German mark, and only 4 of the 11 U.S. purchases of Japanese yen were associated with a same-day dollar depreciation against the Japanese yen (see table 2). In both cases, the observed number of successes is smaller, but not statistically different, than the number that we would randomly anticipate given the variable pattern of day-to-day exchange-rate movements. The evidence of success is somewhat more favorable when judged on a leaning-against-the-wind criterion. During 7 of the 24 days on which the United States bought German marks, the pace of the dollar's appreciation slowed relative to the previous day. This number is two standard deviations greater than the expected number of successes. Similarly, during 5 of the 11 days on which the United States purchased Japanese yen, the pace of the dollar's appreciation slowed relative to the previous day. 
This number was also greater than two standard deviations above the expected number of successes.

Bagshaw and Humpage (1986), using an entirely different statistical technique, found that intervention during the minimalist period had little effect. They compared exchange-rate volatility during a sub-sample of the minimalist-intervention period-1 April 1981 to 31 March 1982 - with a period of heavy intervention - 1 March 1980 to 28 February 1981. They found virtually no evidence of a change in volatility over the two periods, except some tendency for relatively large exchange rate changes to be more common during the minimalist period. ${ }^{17}$ In addition, they found that exchange rates generally were no more volatile than other asset prices over the two periods.

\section{From the Plaza to the Louvre: $1985-1987$}

On 3 February 1985, James Baker replaced Donald Regan as U.S. Secretary of the Treasury. Over the next three years, he pursued macroeconomic-policy coordination to resolve perceived global imbalances much more vigorously than his predecessor had. Like many in the United States, Baker believed that Germany and Japan relied too heavily on their export sectors and, by extension, U.S. economic growth to drive their economies. Both countries maintained sizable and persistent trade surpluses with the United States. Baker wanted Germany and Japan to spur economic growth internally through the adoption of expansionary fiscal and monetary policies. Both countries had experienced relatively sluggish economic growth since the last recession and, hence, had ample room to expand. Not only would faster growth in Germany and Japan help alleviate global current-account imbalances, but it would reinforce the world economic expansion at a time when the U.S. economy showed signs of slowing (Volcker and Gyohten 1995). ${ }^{18}$

Baker was also free to toss foreign-exchange-market intervention into the policycoordination mix, since - unlike his predecessor - he had never objected to such operations. The Plaza interventions in late 1985 sought to lower the dollar and to avoid protectionist threats emanating from the U.S. Congress. By 1987, with the dollar now depreciated, the Louvre interventions attempted to stabilize the dollar-yen and dollar-mark exchange rates. The administration then used the threat of backing away from the Louvre agreement and letting the dollar depreciate anew to gain leverage over Germany and Japan for macroeconomic-policy coordination.

\section{The Plaza Accord}

The dollar began to depreciate in late February 1985, shortly after Baker took office, but well before the September Plaza accord. The Federal Reserve had tentatively started to ease monetary policy in late 1984 and continued to do so through 1986 (see figures 3 and 4). By August, the dollar had depreciated 9 percent on a trade-weighted basis against the currencies of the major developed countries, but late in that month the dollar's depreciation began to reverse as interest-rate spreads moved temporarily in favor of dollar assets. Money growth had exceeded its target, and many Fed watchers thought that the FOMC would act to rein it back into its target range. By mid September, the dollar had appreciated 8 percent against the German mark and 3 percent against the Japanese yen. Although the dollar subsequently began to depreciate, even prior to the G5 meeting in New York, this "pause" lent support to those who thought the dollar had lost touch with fundamentals and who favored coordinated intervention. ${ }^{19}$ 
The 22 September 1985 (or Plaza) communiqué of the G5 noted that although some progress towards macroeconomic convergence had been made, exchange rates had not responded fully. The Plaza accord said that "exchange rates should better reflect fundamental economic conditions than has been the case," and that "some further orderly appreciation of the main nondollar currencies is desirable," and that the G5 "stand ready to cooperate more closely to encourage this when to do so would be helpful.,"20

Funabashi (1988, pp. 17-8) and Frankel (1994, p. 304) contend that the G5 agreed to specifics about intervention as spelled out in a "nonpaper," which was never released. The paper targeted a 10 to 12 percent depreciation of the dollar over the near term. ${ }^{21}$ This would place the dollar in a range of roughly 214 to 218 against the yen and 2.54 to 2.59 against the mark. Once key exchange rates reached these levels, countries would be relieved of their obligation to intervene, but the agreement, of course, did not preclude further collective or individual interventions.

Following the Plaza meeting, the dollar fell sharply, even before any intervention had taken place. On Monday morning, 23 September 1985, the dollar had fallen 5 percent against the German mark and 2.6 percent against the Japanese yen since the previous Friday. The Bundesbank began intervening on Monday in the European markets, selling \$8 million. Later in the day, when the New York market opened, the United States began buying German marks and Japanese yen. With Japanese markets closed on that Monday, the Bank of Japan did not begin intervening until Tuesday, 24 September 1985. Over these first three days, the United States and the other G5 central banks collectively intervened in "massive" amounts (Bulletin February 1986, p.110).

The dollar depreciated sharply against both the mark and the yen until 4 October 1985, as the United States sold \$199 million against German marks and \$262 million against Japanese yen. As the dollar began to firm somewhat after 4 October, the United States intensified its intervention efforts selling nearly $\$ 1.6$ billion against marks and nearly $\$ 618$ million against Japanese yen during the middle two weeks of October. Central banks in other large developed countries continued to intervene (Bulletin February 1986, p. 110 - 111). After this, intervention efforts rapidly tapered off and by 8 November the Plaza efforts ended. Overall, the United States sold nearly $\$ 1.9$ billion against German marks and just over $\$ 1.4$ billion against Japanese yen. The U.S. Treasury's and the System's accounts shared equally in the operations. The interventions were closely coordinated with the Bank of Japan and the European G5 countries (Bulletin February 1986, p. 111). Germany sold $\$ 1.2$ billion. All of the operations were highly visible to the market, suggesting that the operations sought to influence expectations.

During this period, the Desk sometimes intervened in the Far East, which it had not done in quite a while, but the Desk did not buy Japanese yen. ${ }^{22}$ When the Japanese were operating in their own market against dollars, the United States transacted in the Far East in German marks to show evidence of a coordinated approach. These operations also were typically visible to the market (FOMC Transcripts 4-5 November 1985, p. 1).

Although the operations were intended to encourage the dollar depreciation that was already under way, the Desk did not lean with the wind in a traditional sense. That is, the Desk did not buy foreign exchange when the dollar was depreciating. Instead, the Desk only bought foreign exchange when the dollar was rising as a way of resisting appreciations. According to Cross (FOMC Transcripts 1 October 1985, p. 2), "U.S. authorities did not want to push the 
dollar down in a way that could start an uncontrolled fall." Volcker's concern about the dollar had shifted; he now worried about a hard-landing scenario - a dollar free-fall, as he called itthat would put upward pressure on interest rates and prices in the United States and, thereby, complicate monetary policy.

The hard-landing scenario envisioned international investors shifting quickly out of dollar-denominated assets to avoid capital losses associated with a dollar depreciation. The U.S. net international investment position was shrinking because of persistent U.S. current-account deficits, and it would become negative by 1986, implying that the rest of the world held net claims against the United States. If U.S. current-account deficits continued, at some point, international investors would become increasingly reluctant to add additional dollar-denominated assets to their portfolios without compensation for the growing risks of doing so. Then, as their reluctance grew, the dollar would depreciate in the spot market relative to its forward rates and U.S. real interest rates would rise relative to rates abroad. These adjustments would proceed until they raised the foreign-currency return on dollar-denominated assets and provided investors with ample compensation for the perceived risk of holding them.

At question was the speed with which such a development might play out. A smooth adjustment would have few adverse economic consequences for the United States, but a very rapid adjustment could be cataclysmic, and any attempt to push the dollar down, Volcker feared, might trigger a rush out of dollar-denominated assets. The concern that Volcker voiced helps explain why U.S. intervention operations, even during this cooperative period, remained fairly limited (see Volcker and Gyohten 1992, pp.244-247).

The primary effect of the Plaza accord was to induce an immediate, short-lived depreciation of the dollar against both the German mark and the Japanese yen, through a narrow expectations channel (see figures 7 and 8). According to the System's review of the episode (Bulletin February 1986, p.110), market participants interpreted the accord's announcement, which was unanticipated and the product of a U.S. initiative, as signaling a change in the administration's regard for a strong dollar. For one thing, the minimalist approach seemed to have ended. Under its minimalist strategy, the administration intervened only to "counter conditions of clear and manifest disorder." Now, the administration was actively trying to push the dollar down and to bring exchange rates back in line with perceived fundamentals. Most important for exchange rates, however, the Plaza accord reduced the chances that the System would tighten reserve conditions even though aggregates exceed their target range. Many market participants expected U.S. monetary authorities to lower interest rates, possibly in conjunction with interest-rate cuts among the other G5 countries, but in a manner that reduced the incentive for investing in dollar-denominated assets and that, thereby, fostered a dollar depreciation (Bulletin May 1986, p. 299). During the Plaza episode, both nominal and real Japanese shortterm interest rates rose sharply, while nominal and real German short-term rates also drifted up. Consequently, nominal and real interest-rate spreads tended to move in a direction that fostered a dollar depreciation (see figures 5 and 6).

The dollar's one-time depreciation against both the German mark and Japanese yen, by and large, seems associated largely with the Plaza announcement and not with the subsequent intervention. ${ }^{23}$ The dollar opened lower in New York against both the mark and yen on that Monday compared with Friday, even before the United States intervened. (Of course, this depreciation — at least against the German mark — could have been a response to the German intervention, which was already underway.) Humpage (1988), using simple regression 
techniques, found no relationship between intervention and subsequent day-to-day exchange rate movements during the Plaza period. Feldstein (1986), using exchange-rate data at both a monthly and a weekly frequency, concluded that Plaza interventions essentially produced a onetime downward shift in key exchange-rates, but did not otherwise alter their trend movements. ${ }^{24}$ Whereas intervention, itself, seems to have had no clearly discernable, persistent effects on exchange rates, monetary policies between the United States and German and, especially, between the United States and Japan changed in manners consistent with dollar depreciations. Subsequent policy validated the expectations that the Plaza accord created, at least for awhile.

The effects of the Plaza agreement began to wear off by early October because policy makers in the G5 countries were no longer reinforcing or substantiating expectations of additional policy initiatives to drive the dollar lower. The dollar actually appreciated 3 percent against the mark between 4 October and 16 October 1985. The market, which anticipated additional policy initiatives on the part of the G5 countries, began to lose confidence when the recent IMF and International Bank for Reconstruction and Development meetings focused on the international-debt situation rather than on macroeconomic convergence. Moreover, Bundesbank President Pöhl quickly expressed satisfaction with the extent of the dollar depreciation.

According to Destler and Henning (1989, p. 50), Pöhl announced that the dollar had reached an acceptable level in a little more than two weeks after the Plaza declaration, when the dollar had depreciated only about 7 percent against the German mark. Funabashi (1988, pp. 301) notes that the United States criticized Germany for not intervening more following the Plaza agreement. He maintains that in part the Europeans saw the dollar chiefly overvalued against the yen. In addition, Funabashi notes that the EMS constrained German actions. If the Germans had undertaken much larger dollar sales, the mark risked appreciating within the EMS, since the Bundesbank could not quickly sterilize the intervention. In the Germany's view, other European countries needed to sell more dollars in order to maintain the EMS (Funabashi 1988, pp. 30-1).

This criticism of Pöhl's announcement may be justified, but, nevertheless, the Bundesbank sold nearly as many dollars as the United States. Between 23 September 1985 and 8 November 1985, the Bundesbank sold approximately $\$ 1.2$ billion, while the United States bought nearly $\$ 1.9$ billion equivalent German marks. Moreover, by early November, Federal Reserve officials, like their German counterparts, were busy denying the existence of any agreement to encourage a dollar depreciation by manipulating international interest-rate spreads (Cross, Winter 1985-86, p. 47)

While the intervention may have had a signaling effect — causing market participants to anticipate further reductions in interest rates-Volcker suggests that within the System, the dollar's depreciation dampened the FOMC's ardor for monetary ease. To be sure, monetary policy in the United States eased as growth slowed and inflation moderated. Many Federal Reserve Banks, however, were requesting a discount-rate reduction, which forecasted their intended policy stance at the next FOMC meeting. "But with the dollar already declining so sharply, the balance of the argument to me [Volcker] and most of my colleagues was the other way. Without clearer evidence that the expansion had petered out, easing money in the face of a rapid decline in the dollar seemed too much like pouring Federal Reserve oil on a fire already burning that I wanted to keep under control.” (Volcker and Gyothen 1992, p. 247)

Over all during the Plaza episode (20 September to 8 November 1985) the dollar depreciated nearly 8 percent against the German mark and 14 percent against the Japanese yen. 
The dollar stood at 2.62 marks per dollar on 8 November 1985, not quite in the 2.54 to 2.56 range that Funabashi suggested was an implicit target. The dollar did, however, slide beyond the 214-218 yen per dollar implicit target that Funabashi mentioned to 205.6 on 8 November 1985.

The slight variation between the Japanese yen and Germany mark might have resulted because the Japanese monetary authorities were not as quick as their West German counterparts to disavow their currency's appreciation. The dollar continued to depreciate against the Japanese yen through early November 1985. Officials at the Bank of Japan and at the Japanese Finance Ministry had announced on October 15 additional policy changes to encourage a yen appreciation. Yen interest rates rose, especially short-term interest rates.

\section{Between Plaza and Louvre}

Throughout 1986, the dollar depreciated on balance in an orderly manner against all major currencies, particularly the Japanese yen. The overall dollar depreciation seemed consistent with the continuing worldwide trade imbalances and with general trends in interestrate differentials. With the dollar now depreciating in an orderly fashion, consistent with the perceived fundamentals, the United States saw no need to intervene. Between mid-November 1985 and the Louvre accord in February 1987, the United States intervened on only two occasion in very small amounts. ${ }^{25}$

Other key central banks, however, bought substantial amounts of dollars throughout 1986 and January1987. As early as March 1986, the Japanese started to view the Plaza accord as a mistake, because they believed that it kicked off a persistent yen appreciation, which continued through 1988. Japanese exporters, particularly small to medium-sized firms, complained (Volcker and Gyothen, 1992, p. 256).

U.S. Treasury Secretary Baker, who had been trying to get Germany and Japan to stimulate their economies, wanted the G5 to undertake coordinated interest-rate cuts in part to offset the global effects of a projected slowing in U.S. real economic growth, in part to help developing countries with their debt problems, and in part to alleviate global current-account imbalances. The $\mathrm{G} 7$ ministers and central-bank governors began meeting regularly to promote policy coordination, specifically a convergence among their monetary policies. Baker threatened that if the G7 did not participate, unilaterally lower U.S. interest rates would cause further dollar depreciation. Volcker, who continued to worry about a hard-landing scenario for the dollar, was not in favor of unilateral interest-rate cuts, particularly when dictated by the U.S. Treasury. The Reagan appointees on the Board of Governors, however, advocated monetary ease.

Volcker had already discussed the need for coordinated interest-rate cuts with the Bank of Japan and with the Bundesbank, but to no avail. On 24 February 1986, the Federal Reserve Board voted 4 to 3 to cut the discount rate over Volcker's objection. After Volcker threatened Vice-Chairman Preston Martin and Governor Wayne Angell with his resignation, the Board agreed to wait. Volcker and Pöhl subsequently agreed to undertake coordinated rate cuts in March after the Bundesbank's next policy meeting. On 6 and 7 March 1986, Germany, France, Japan, and the United States undertook coordinated interest-rate cuts. Vice-Chairman Preston Martin resigned on 31 March 1986 (see figure 9). On 21 April 1986, the Board undertook another rate cut that was coordinated with the Bank of Japan. ${ }^{26}$

The Federal Reserve undertook two unilateral discount rate cuts on 11 July 1986 and 21

August 1986 and may have been trying to encourage Germany and Japan to take further steps to 
stimulate their economies. According to Funabashi (1988, p. 53), when Volcker pressed, "Pöhl responded that he and his colleagues would consider a rate cut, but only with the stipulation that Baker announce publicly after the next G5 meeting that the United States was prepared to stabilize the dollar. Volcker promised to discuss the proposal with Baker.” Baker, however, rejected the idea.

With Germany and Japan now concerned about further dollar depreciation, Baker continued with his strategy of trying to persuade countries to adopt expansionary policies under the threat of a dollar depreciation. At the Tokyo Summit in May 1986, the G7 avoid discussion of exchange rates, but agreed with a U.S. proposal for adopting a wide array of economic indicators and quantitative objectives by which to judge countries' economic performances.

In September 1986, Baker met secretly with Japanese Finance Minister Kiichi Miyazawa in San Francisco. The U.S. reaffirmed its commitment to the Gramm-Rudman-Hollings deficitreduction act, and the Japanese agreed to an expansionary supplemental fiscal package. Both countries claimed that the dollar was consistent with fundamentals - after allowances for these fiscal proposals - and agreed to stabilize the dollar. By the time that the deal was announced in October 1986, however, the yen had depreciated sharply, albeit temporarily, and U.S. officials suspected that the Japanese had deliberately engineered the depreciation to take advantage of the agreement (see Frankel 1994, p. 306).

\section{Louvre Period: 1987}

By early 1987, the dollar had reversed nearly all of the real and nominal appreciation that it experienced between 1981 and 1985, but global trade imbalances had not yet shown any improvement and remained a contentious political issue. The U.S. current-account deficit remained around $3 \frac{1}{2}$ percent of GDP; the net international investment position had now become negative, and both Germany and Japan continued to post substantial current-account surpluses. Private foreign investors seemed increasingly reluctant to acquire dollar-denominated assets (Loopesko and Johnson 1987). The dollar continued to depreciate, but at a more modest pace, and interest-rate spreads widened to attract private financial flows. Germany and Japan became even more reluctant to stimulate their economies since both were concerned about money growth and inflationary pressures. At the same time, neither wanted to encourage a further dollar depreciation. Many believed that a pause in exchange-rate realignments was needed to allow the recent adjustments to feed through and to prevent an overshoot on the downside (Dobson 1991, p. 61).

In January 1987, the dollar came under heavy selling pressure that contributed to a realignment of central rates within the European Monetary System. Despite the problems in the EMS, much of the dollar's movement in January occurred relative to the Japanese yen, and it prompted heavy Japanese intervention (Bulletin May 1987 p. 333). On 28 January, the United States intervened in a "hectic and nervous" market, selling a small amount ( $\$ 50$ million equivalent) of yen (Cross Spring 1987a). The intervention followed statements reaffirming cooperation among the major central banks. A 1.2 percent appreciation of the dollar relative to the yen followed, and the yen-dollar rate remained relatively stable through mid-March.

The dollar seemed to stabilize in February, following the release of more favorable trade data in late January 1987. At the 22 February 1987, Louvre meeting of the G6 - the G5 plus Canada (Italy abstained) - the United States pledged to stabilize the dollar in return for a Japanese and German commitment to additional economic stimulus. Japan agreed to cut its 
discount rate and to submit a supplemental budget to stimulate domestic demand, and Germany agreed to increase planned 1988 tax cuts. For its part, the United States also reiterated its Gramm-Rudman-Hollings targets for deficit reduction (Destler and Henning 1989, p. 60).

With respect to exchange rates, the Louvre communiqué (paragraph 10) stated that "...the substantial exchange rate changes since the Plaza Agreement will increasingly contribute to reducing external imbalances and have now brought their [the G6 countries'] currencies within ranges broadly consistent with underlying economic fundamentals... Further substantial exchange rate shifts among their currencies could damage growth and adjustment prospects in their countries. In current circumstances, therefore, they agreed to cooperate closely to foster stability of exchange rates around current levels." 27

Funabashi (1988, pp. 185-187) claims that the G6 agreed to secret targets for the markdollar and yen-dollar exchange rates at their Louvre meeting. ${ }^{28}$ His narrative, however, is not clear about how seriously the delegates actually took any targets. They were not widely favored, and any obligation seemed vague and open to interpretation. ${ }^{29}$ Indeed, Treasury Secretary Baker said on 23 March 1987 that the G6 did not set target zones for dollar exchange rates. We can find no statement of the targets in published Federal Reserve documents, but Volcker and Gyohten (1992) contend that target ranges had been discussed within the U.S. Treasury for some time prior to the Louvre. According to Funabashi (1988, p. 186):

"In the final hour of the Louvre dinner, de Larosiére and Darman worked together to give final shape to a joint proposal. Two specified midpoint rates were agreed: 1.8250 deutsche marks to the dollar and 153.50 yen to the dollar; plus or minus 2.5 percent was determined as a first line of defense for mutual intervention on a voluntary basis, while at 5 percent consultation on policy adjustment was to be obligatory; between these limits of 2.5 percent to 5 percent, intervention efforts were expected to intensify. All the agreements were to be kept strictly confidential and were provisional until the Washington G-5 meeting in April."

The French seemed to favor target zones, and the U.S. Treasury was receptive to the idea, but the Germans and the British did not want target ranges (Funabashi, 1988, pp. 183-186).

The 2.5 percent range for the yen was 149.75 to 157.33 and the 5 percent range was 146.19 to 161.7 . The 2.5 percent range for the German mark was 1.7804 to 1.8706 , and the 5 percent range for the German mark was 1.73809 to 1.9262 . The targets suggested that mandatory intervention against the Japanese yen would take place when the dollar depreciated below 146.19 or appreciated above 161.17 , but official sales of yen might start as early as 149.75, and official purchases of yen might start at a rate of 157.33. The Japanese, however, did not want the yen-dollar rate to fall below 150. Similarly, mandatory intervention against German marks would take place when the dollar depreciated below 1.7389 or appreciated beyond 1.9262, but official sales of marks might start as early as 1.7804, and official purchases of marks might start at 1.8706 .

The United States, Germany, Japan, and other key central banks did not immediately intervene following the Louvre communiqué. On 11 March 1987, as the dollar rose above 1.8600 marks, the United States bought \$30 million equivalent German marks, but would not intervene again against marks until late April (see figure 10). The dollar continued to appreciate on 11 March, suggesting that the intervention had not been successful, but the dollar began a sustained depreciation on the next day. Less than two weeks later, however, the United States 
began to intervene frequently and very heavily in Japanese yen as heightened trade tensions with Japan sent the dollar below 150 yen (see figure 11). The Desk sold roughly $\$ 3.0$ billion worth of Japanese yen on 11 consecutive days between 23 March and 6 April 1987, often in concert with the Bank of Japan (Bulletin July 1987, pp. 552-553). The FOMC Subcommittee on Foreign Exchange allowed the Desk to exceed daily intervention limits on yen (Desk Report 1988, p. 7). On April 6, according the Funabashi (1988, p. 6), the G6 rebased the yen. They set a new central rate of 146, a 2.5 percent range of 142.43 to 149.65 and a 5 percent range of 139.04 to 153.30 . Then, through the end of April 1987, the Desk sold an additional $\$ 1.0$ billion worth of yen, often in concert with the Bank of Japan and several European banks (Bulletin July 1987, p. 555). The Bundesbank, however, did not participate in these interventions. The operations had little obvious effect on exchange rates (see figures 10 and 11).

Baker was upset with the Germans for not acting in concert. The Bundesbank did not intervene until late in April because it "feared that massive interventions to prop up the dollar would swell West Germany's currency reserves and create excessive liquidity.” (Funabashi, 1988, p. 191). In 1979, the Bundesbank-like the Federal Reserve-began to pursue a goal of price stability, and it adopted monetary targets to improve the credibility of its commitment. The Bundesbank overshot its monetary targets in 1986, and it would do so again in 1987 and 1988 in part because of attempts to resist an appreciation of the mark (Hetzel 2002, pp. 50-51; Kole and Meade 1995, pp. 917-931). Because of these persistent monetary overshoots, the Bundesbank was unenthusiastic about any policy coordination or intervention that ascribed to Germany an expansionary obligation.

Neumann and von Hagen (1991) show that the German Bundesbank has often permitted deviations between actual money growth and targeted money growth because of exchange rate considerations. Von Hagen (1989) also argues that when the market is strong against both the dollar and the ERM currencies, the Bundesbank did not permanently sterilize its interventions. ${ }^{30}$

The situation was similar for Japan. Hutchison (1988) indicates that the Bank of Japan factored an exchange-rate objective into its monetary-policy decisions between 1978 and 1985, and Takagi (1989) claimed that after late 1985, the Bank of Japan allowed intervention to affect its monetary base.

In late April and early May 1987, U.S. interest rates continued to firm, and "market participants became impressed by the Federal Reserve's willingness to adjust monetary policy to support the dollar, as well as by the complementary policy adjustments taken in other countries. Market observers particularly noted comments made in late April by Chairman Volcker that the Federal Reserve had adjusted monetary policy_-'snugged up' interest rates - to counter exchange-market pressures as well as comments by Japanese Prime Minister Nakasone that the Bank of Japan would ease short-term interest rates." (Desk Report 1988, p. 9-10) The German Bundesbank also seemed to cooperate in the efforts to stabilize the exchange rate by reducing the rates at which it provided liquidity to its banking system. Interest-rate differentials vis-à-vis German mark and Japanese yen denominated assets stood at their widest point since the dollar's peak and began to attract funds into dollars (Desk Report 1988, p. 10). An improvement in U.S. net exports and tensions in the Middle East also buoyed the dollar. As the dollar rose above 1.89 marks, the Desk began to buy German marks.

By May 1987, however, the FOMC began to question the appropriateness of heavy intervention (FOMC Transcripts 19 May 1987, pp. 3-5). At least, the intervention was 
consistent with the thrust of U.S. monetary policy. Intervention continued very intermittently throughout May and June, with the United States selling a relatively small, \$123 million equivalent yen and relatively moderate $\$ 680$ million equivalent German marks, often in concert with other central banks (Bulletin October 1987, pp. 780-781).

The dollar continued to firm until early August. Then, the dollar rose above 1.85 marks, prompting the United States to intervene again against marks. Between 4 and 10 August 1987, the Desk bought $\$ 631$ million worth of marks to resist the appreciation of the dollar against the mark. The Bundesbank sold \$227 million and other G6 monetary authorities participated (Bulletin January 1988, pp. 14 - 15). These interventions had no net effect; on 10 August 1987 the exchange rate was 1.8953 marks per dollar compared with 1.8817 on 4 August 1987.

By 11 August, following the release of poor trade numbers, the dollar turned about and began to depreciate, especially against the Japanese yen. Between 24 August 1987 and 2 September 1987, the Desk sold \$390 million equivalent yen in concert with the Japanese Ministry of Finance (Bulletin January 1988, pp. 14 - 15). Between 28 August 1987 and 18 September 1987, the Bundesbank bought $\$ 414$ million; other central banks intervened to support the dollar (Bulletin January 1988, p. 15). On 2 September 1987, the Desk sold $\$ 50$ million against German marks. Despite the interventions, the dollar continued to depreciate. On 4 September the Federal Reserve increased the discount rate to deal with mounting inflationary pressures. Interest rates in the United States subsequently began to rise.

Although U.S. monetary authorities sometimes bought foreign exchange, the Louvre operations consisted mostly of sales of foreign exchange in an attempt to support the dollar. The Federal Reserve System financed most of the German mark operations during the Louvre period, while the Treasury financed most of the Japanese yen intervention. The operations failed to keep the targeted dollar exchange rates within the envisioned ranges.

The perception of international cooperation started to erode in mid-October 1987. Market participants believed that the Bank of Japan and, particularly, the Bundesbank might raise policy rates and adopt less accommodative monetary policies. Money growth in both countries exceeded targets and contributed to concerns over mounting inflation. Interest rates rose in Germany and Japan, although interest-rate differentials continued to support dollar assets (Desk Report 1988, p. 14).

In September and early October 1987, Secretary of the Treasury Baker publicly criticized foreign interest rate increases as not being in compliance with the Louvre accord. He reportedly threatened Germany with a still weaker dollar, although the administration later denied the reports (NYT 16 October 1987, pp. A1). He also suggested that U.S. interest rates would not follow German interest rates higher.

On 19 October 1987, the stock-market crashed and the Federal Reserve provided sufficient liquidity to the market to lower interest rates. The dollar depreciated sharply against both the German mark and Japanese yen. Baker then met with German Finance Minister Stoltenberg to set aside recent criticisms and to re-affirm their Louvre commitments. They agreed to renewed cooperation on monetary policies and on stabilizing dollar exchange rates. German interest rates subsequently moved substantially lower. By 27 October 1987, the United States began selling German marks and Japanese yen to stem the dollar's depreciation. Between 27 October 1987 and 11 November 1987, the Desk sold \$1.1 billion equivalent German marks and $\$ 443$ million equivalent Japanese yen. Over roughly the same days, the Bundesbank bought 
\$1.4 billion. The Bank of Japan and other central banks also bought dollars in concert with U.S. authorities (Bulletin January 1988, p. 17). The Bundesbank subsequently cut its key policy rates.

Following the stock-market crash, as concerns about a possible recession grew, public support for exchange-rate stabilization efforts began to wane. "Widespread press commentary questioned the priority for the United States of stabilizing exchange rates in view of concerns about the possible impact of the stock market decline on U.S. economic activity." (Desk Report 1988, p. 16) Likewise, “...on December 22 [1987] when the Group of Seven nations issued a statement reaffirming economic policy coordination and stating that a further decline of the dollar could be counterproductive, market participants remained unconvinced that decisive action would be taken to halt the dollar's decline." (Desk Report 1988, p. 18) The market understood that intervening to support the dollar was inconsistent with the need for monetary ease in the United States.

The dollar continued to depreciate and the Desk continued operations to support the dollar. Between 27 November 1987 and 21 January 1988, the Desk sold \$1.7 billion worth of marks and $\$ 1.4$ billion equivalent yen often in concert with other central banks (Bulletin April 1988 pp. 209 - 211). The Bundesbank, for example, bought \$1.7 billion. As Volcker (Volcker and Gyohten 1992, p.269) recalled:

"The [December 1987 G7 communiqué] marked the end of a somewhat confused three-year process, the results of which were not very satisfactory, at least at the time, because all our efforts in aligning exchange rates and coordinating macroeconomic policy had failed to produce tangible, clear results. The external imbalance among major countries - especially the Japanese trade surplus and the American deficit, the two-sided political irritant that has started the whole exercise- did not improve despite the major changes in exchange rate relationships."

\section{Why Policy Coordination Fails}

By the late 1980s, many economists seemed to share Volcker's observations about the recent failure at macroeconomic policy coordination. Myriad empirical papers appeared and concluded that the gains from the types of policies that Treasury Secretaries Baker and Brady had been pursuing within the G5 and G7 were small and asymmetrically distributed, with the United States often benefiting least (see: Humpage 1990, Hamada and Kawai 1997, McKibbin 1997). These studies showed that the theoretical gleam of ongoing macroeconomic policy coordination tarnished quickly when exposed to empirical verification.

In a world where markets are closely integrated, the policy actions of any one nation, particularly those of a large developed country, are certain to affect the wellbeing of other nations. Sometimes these policy spillovers are positive, sometimes they are negative. The existence of such policy interdependencies offers a theoretical justification for macroeconomic policy coordination.

Countries understand these external policy effects, but they evaluate them lopsidedly. They consider the implications of foreign policy action on their own economic well-being, and they set their own policy instruments after taking foreign policies into account, but sovereign nations do not fully consider the implications of their own policies for the economic welfare of other countries. When all countries act this way, they achieve a Nash equilibrium, but better outcomes are conceivably possible. 
Many theoretical models suggest that when countries ignore the consequences of their actions for world welfare, their policies often prove to be suboptimal in the sense that some alternative set of policies, which account for all of the spillover effects, could make at least one country better off without making any other country worse off. Implicitly, these models assume that individual countries do not have enough independent policy instruments to maintain all of their desired policy goals or that the interdependences alter the relationship between countries' domestic policy instruments and their ultimate objectives. In these cases, macroeconomic policy coordination can achieve a welfare improving set of policies.

In most theoretical applications, however, this welfare improving outcome is fragile. Countries often have strong incentives to renege on the coordinated policy once they believe that other countries have adopted it. Consequently, the world tends to gravitate back to the Nash equilibrium. Absent some sort of strict enforcement mechanism, macroeconomic policy coordination may not be sustainable, even in theory.

The emerging empirical studies went beyond this theoretical fragility and suggested at least three conditions under which macroeconomic policy coordination could be welfare reducing: First, for macroeconomic policy coordination to enhance welfare relative to noncooperative policies, policymakers - even different policymakers within a single country-must have similar preferences for such objectives as inflation, real economic growth (or full employment), exchange rates, and current-account positions. If fiscal policy makers coordinate across countries, but monetary policy makers have different objectives (e.g., a primacy of price stability) and do not coordinate with their fiscal counterparts, the outcome need not be Pareto superior to the non-cooperative outcome. Second, macroeconomic policy coordination requires that policy makers coordinate under the true economic model. Coordinating macroeconomic policies internationally under an incorrect model may leave nations worse off relative to no coordination (Frankel and Rocket 1988, Holtham and Hughes Hallet 1987, Ghosh and Mason 1987). The gains to a single country from discovering the true economic model and moving to it are often greater than any gains from policy coordination. To be sure, this information problem occurs in a purely autarkic setting, but then policy multipliers under both the true and false model typically differ by degree, not direction. In large, open-economy models, multipliers often differ in terms of sign, hence coordinating under the wrong model can be destructive. Third - and most important - macroeconomic policy coordination can affect government credibility relative to the private sector with important implications for welfare. Rogoff (1985) constructs an example in which coordination eliminates the exchange rate as a constraint on fiscal authorities' inflation bias, thereby adversely affecting inflation expectations. Concerns about the effects of policy coordination on monetary-policy credibility came to affect FOMC participants.

\section{An Analysis of the Plaza and Louvre Interventions}

Many analysts seem to regard both the Plaza and the Louvre operations as clear examples of successful macroeconomic coordination and sterilized intervention, but our narrative and statistical evidence are less supportive. We find some evidence that official U.S. sales of German marks and Japanese yen moderated dollar depreciations against these currencies, but we find no support for the view that intervention fosters appreciations or depreciations in a manner ultimately necessary to maintain target zones - a consideration particularly important for the assessment of intervention over this period. 
As suggested throughout our previous narrative, most of the movements in exchange rates over the Plaza and Louvre period seem attributable to policy changes, not intervention. On this point, Obstfeld (1990, p. 199) seems to agree:
"The conclusion reached is that monetary and fiscal policies, and not intervention per se, have been the main policy determinants of exchange rates in recent years [1985-88]. Pure intervention seems to have played an effective signaling role, in the sense of speeding desired exchange rate movements or impeding undesired ones, when promptly backed up by other, more substantive policy adjustments. But the portfolio effects of pure intervention have generally been elusive enough that interventions cannot be regarded as a macroeconomic policy tool in their own right, with an impact somehow independent of short-term decision on monetary and fiscal policy."

Our analysis, while not directly testing any specific channel of influence, nevertheless, seems more consistent with a signaling channel than a portfolio view. By the mid-1980s, academic explanation of how intervention might affect exchange rates largely relied on a narrow signaling channel, which held that interventions signaled unanticipated changes in future monetary policy to the market. The Jurgensen Report, after all, concluded that sterilized intervention was largely ineffective if not accompanied by supporting monetary-policy changes. Empirical studies of the narrow signaling channel undertaken in the late 1980s and early 1990s, however, offered little supportive evidence. ${ }^{31}$ Eventually a broader concept of an expectations channel emerged and would henceforth guide most empirical work. This view held that although foreign exchange markets were highly efficient, they were subject to temporary inefficiencies (see Baillie, et al. 2000, Humpage 1991). If central banks had better information about fundamentals in general, they might still affect exchange rates through their intervention. This is a testable proposition.

Over the 805 business days between 1 April 1985 and 29 April 1988, a period that encompasses both the Plaza and Louvre interventions, the United States sold German marks on 33 days and bought German marks on 19 days. ${ }^{32}$ Only 11 of the mark sales were associated with a same-day dollar appreciation and only 8 of the mark purchases were associated with a sameday dollar depreciation (see table 3). Given the variable nature of day-to-day exchange-rate changes, however, we expect to find that 14 of the mark sales were associated with a dollar appreciation and that 10 of the mark purchases were associated with a mark depreciation purely by chance. The observed number of successes is no less than one standard deviation of the expected number, and, hence, the number of successes is no different than random. (The empirical appendix explains our analytical technique.)

Likewise over this same period, the United States sold Japanese yen on 52 days and bought Japanese yen on 20 days. Only 25 of the Japanese yen sales were associated with a same-day dollar appreciation against the yen and only 10 of the yen purchase were associated with a same-day dollar depreciation against the yen. Although the 25 successes out of 52 yen sales is two more than we would anticipate, the count still falls within one standard deviation of the expected number of successes and, consequently, seems no better than random. Likewise, the 10 successful purchases of Japanese yen appear no greater than the number we would randomly anticipate given the variations in near-term exchange-rate movements. These results for the U.S. yen interventions, like the ones for U.S. mark interventions, indicate that sterilized 
intervention could not have maintained a target zone, since intervention could not force an exchange rate, once out, to return to within the target range.

The evidence in favor of success is slightly stronger when we define success in terms of a leaning-against-the-wind criterion. Eleven of the 33 U.S. sales of German marks, for example, are associated with a smaller dollar depreciation against the German mark on the day of the intervention than occurred on the previous day. Eleven exceeds the expected number of successes (five) by more than two standard deviations, suggesting that number of successes was not a random event. Likewise four out of the 19 U.S. intervention purchases of German marks are associated with smaller dollar appreciations against the mark on the day of the intervention as compared to the previous day's appreciation. Four equals the expected number of successes plus two standard deviations under our leaning-against-the-wind criterion, again suggesting the number of successes is not a random event. Intervention against the German mark appears to have moderated movements in the dollar.

The results for intervention against Japanese yen are similar, but a bit weaker than those for the German mark. Of the 52 U.S. sales of Japanese yen, 10 were associated with a smaller dollar depreciation on the day of intervention as compared with the dollar's depreciation on the day before the intervention. Ten is greater than the expected number of successes, but is one shy of two standard deviations greater. Of the 20 U.S. purchases of yen, two were associated with a smaller same-day dollar appreciation. Two is equal to the number of successes that we would randomly anticipate given the volatile nature of daily exchange-rate movements. So, with respect to the yen the tests at best mixed.

Altogether, approximately 65 percent of the U.S. interventions against either of these currencies appeared successful under one or the other of our success criteria. The observed overall success counts - both criteria combined - were never more than two standard deviations above the expected number of successes, suggesting that the overall outcome was random.

\section{The End of the Activist Agenda: 1988-1995}

Ever since the Federal Reserve System began intervening in the foreign-exchange market, FOMC participants had frequently questioned the effectiveness of the transactions, the appropriateness of the System's involvement with the U.S. Treasury, and the operation's potential for raising Congressional ire. After the 1987 stock-market collapse, these questions arose anew, but now they took on a new distinctive tone: FOMC participants criticized intervention because they worried that the operations interfered with the credibility of the System's commitment to price stability.

By the late 1980s, the FOMC was trying to consolidate gains from its prolonged fight against inflation. Discussions of monetary policy focused on building credibility and included such issues as: rules versus discretion, central-bank independence, and inflation targeting. Many FOMC participants felt that in the absence of a legislated numerical mandate for price stability, anything that even suggested behavior inconsistent with that goal could damage the System's integrity. Intervention was just such a thing, and attitudes soon reached a tipping point.

The FOMC's objections to intervention became three-fold. First, although legally independent, the Federal Reserve System had little choice but to participate with the U.S. Treasury in major foreign-exchange operations. This was especially true when the Treasury decided exchange-rate policies within G5 or G7 forums. Consequently, intervention gave the 
fiscal authority leverage over an independent central bank and weakened that bank's commitment to price stability. Second, FOMC participants - recalling the Jurgensen Reportfeared that if markets interpreted sterilized intervention as a signal of future monetary-policy changes, intervention would create uncertainty about the System's commitment to price stability. ${ }^{33}$ The dollar often appreciated when the FOMC tightened. Consequently, the Desk could find itself buying foreign exchange, ostensibly adding reserves to the banking system, at the same time that it drained reserves through open-market operations in pursuit of price stability. A third argument against intervention noted that operations to offset dollar appreciations and warehousing with the U.S. Treasury left the System holding foreign-currency assets on its books. Losses on the foreign-exchange portfolio could lead Congress to accuse the System of mismanagement or, in the case of warehousing, of interfering with the appropriations process. Such criticisms could lead to policies that might impinge on the System's independence.

Stock Market Collapse

Frictions between U.S. monetary policy and foreign-exchange intervention first heated up within the FOMC shortly after the 19 October 1987 stock-market crash. On the following day, the Federal Reserve provided liquidity to the market and moved quickly to lower the federalfunds-rate target by 50 basis points to 7 percent. Over the next few weeks, the System used high-profile techniques to inject liquidity into the banking system (Carlson 2006). As interest rates in the United States fell faster than rates abroad, the dollar dropped below 1.76 marks and 141 yen, prompting heavy concerted intervention to support the dollar, which we previously explained.

Although the Desk automatically sterilized interventions that were incompatible with its federal-funds-rate target, its sales of foreign exchange after the stock-market collapse seemed inconsistent with the FOMC's efforts to inject liquidity into the banking system. At the 3 November 1987 FOMC meeting, Robert Forrestal, President of the Federal Reserve Bank of Atlanta, noted the incompatibility of the Desk's operations: “...I find it a little anomalous that we are draining reserves to defend the dollar while, at the same time, we are adding reserves to add liquidity to the domestic economy." (FOMC Transcripts 3 November 1987, p. 2)

The discussions that followed suggested that many FOMC participants wanted to focus on price stability and to ease out of frequent foreign-exchange interventions, but Sam Cross, an advocate of an activist approach, argued that the System had no choice but to intervene at the Treasury's behest. Although the Federal Reserve had independent authority for intervention, it was obliged to cooperate with the Treasury on international financial matters, according to Cross. He described a failure to do so as a major event, one requiring prior consultation with Congress. Barring Congressional approval, Cross claimed, the System's only option was to attempt to influence the Treasury's decisions about intervention from a cooperative and accommodating position (FOMC Transcripts 3 November 1987, p.6). Cross seemed to echo Chairmen Martin's interpretation of Federal Reserve independence: the System is independent within - not of - government. This view, however, appeared inconsistent with price stability to many on the Committee.

To be sure, the conflict between monetary policy and intervention from late October 1987 through mid-January 1988 did not seriously jeopardize the FOMC's commitment to price stability. The System eased policy to avoid a financial crisis. The federal-funds-rate target 
declined, but the real federal funds rate remained little changed (see figures 3 and 4). The Desk's intervention sales of German marks and Japanese yen were at least consistent with the FOMC's longer-term inflation fight.

During the first half of 1988, intervention and monetary policy became compatible. The U.S. economy proved more resilient than many thought at the time of the stock-market crash, allowing the FOMC to renew an anti-inflation policy thrust by March 1988. The Desk sold moderate amounts of Japanese yen and German marks in brief interventions in late March and mid-April 1988. So the Desk's foreign operations appeared consistent with its domestic objective of draining reserves.

In late June 1988, however, the situation changed. The FOMC remained concerned about prospective inflation and raised the federal funds rate. The dollar began to appreciate sharply, especially relative to the German mark. To moderate the dollar's rise, the United States began a series of very large, very persistent purchases of German marks. In all, between 27 June and 26 September 1988 , the Desk bought $\$ 5.1$ billion equivalent German marks, a massive amount. The Bundesbank sold $\$ 8.8$ billion and increased its policy rates.

Initially, FOMC participants attributed the dollar's appreciation largely to temporary speculative activity, implying that the intervention would be limited and not prejudicial to the Committee's inflation fight (FOMC Transcripts 29 \& 30 June 1988, pp. 1-7). As official purchases of marks persisted, however, the FOMC discarded this view, and its tone began to change. At the 16 August 1988 FOMC meeting, Vice Chairman Corrigan unwittingly initiated a renewed debate about intervention when he applauded the recent interventions for curtailing the dollar's rise. This was an argument that he could not empirically substantiate. ${ }^{34}$ Corrigan argued that the nature of the foreign-exchange market had changed over the last few years. The volume of trading had grown enormously, and program trading strategies increased the likelihood of oneway markets and of overshooting. He argued that intervention "does play a useful role in reaffirming the fact that there are two-way markets." (FOMC Transcripts 16 August 1988, p. 2).

Other FOMC members, notably Governors Wayne Angel, Robert Heller, Manual Johnson, and Federal Reserve Bank of Cleveland President Lee Hoskins, argued that markets generally functioned well. Governor Heller, for example, agreed that a large intervention, hitting a one-way market potentially could have an effect, but he worried that such an intervention created uncertainty, which could reduce the incentives for taking positions and could actually raise volatility (FOMC Transcripts 16 August 1988, p. 3). ${ }^{35}$ President Hoskins questioned what a one-way market really was, other than a sustained bidding up of the price. Why was this necessarily evidence of a market failure? Hoskins allowed that markets might occasionally be disorderly, as in a panic or crash, but these were very infrequent events, and intervention should be equally infrequent. A disorderly market argument in no way justified intervention at the frequency he had recently observed (FOMC Transcripts 16 August 1988, p. 4). Governor Johnson, echoing to some extent Governor Angel, argued that intervention interfered with monetary policy: "when we are doing consistent interventions and it's working in the other direction from our open market operations, it does run the risk ... of confusing the federal funds market as to what our reserve needs may be. ... Maybe we want the two-way risk on the foreign exchange market, but we don't want this uncertainty in the open market operations." (FOMC Transcripts 16 August 1988, p. 5) 
The United States continued to buy German marks through September 1988, but shortly thereafter the dollar depreciated. From 31 October 1988 through 2 December 1988, the Desk sold nearly $\$ 2.0$ billion worth of Japanese yen and \$0.6 billion worth of German marks. At the 1 November 1988 FOMC meeting, President Hoskins pointed out that intervening over a fairly short period of time on both sides of the market suggested that the Desk knew the "right" exchange rate, which seemed unlikely. This, of course, was not a new criticism, but emblematic of the changing views among many FOMC participants, Hoskins continued: “... by doing this I think we continue to confuse the public as to what our [monetary] policy is all about and divert attention from our long-term objective of stable prices. And secondly, I think we run the risk of confusing ourselves as to our abilities to influence exchange rates in an appropriate fashion." (FOMC Transcripts 1 November 1988, p. 13) Indicative of changing attitudes, Hoskins worried first of all that intervention interfered with monetary policy; his secondary concern was about its effectiveness.

During the first half of 1989, the dollar once again appreciated, and the United States undertook an unprecedented amount of intervention, so much so, that the Desk had to request two inter-meeting increases in its limits on intervention (FOMC Transcripts Cross Report, Appendix 5, July 1989, p. 3). The authorizations for the net-open position increased from $\$ 12$ billion to $\$ 18$ billion (see figure 12). The Desk bought $\$ 8.5$ billion worth of German marks and nearly $\$ 7.2$ billion worth of Japanese yen during the first half of the year. Germany, which had been selling dollars since mid-December 1988, sold $\$ 7.2$ billion. The U.S. operations against both German marks and Japanese yen were split equally between the System's and the Treasury's accounts, but the System warehoused $\$ 3.0$ billion worth of German marks for the ESF in June 1989, thereby helping to finance its interventions. By September 1989, the authorization for warehousing had reached $\$ 10$ billion (see figure 13).

The real federal funds rate remained high during this time, suggesting that the FOMC kept a relatively tight monetary-policy stance. Consequently these huge, Treasury directed, intervention purchases of foreign exchange once again appeared inconsistent with the design of monetary policy. The operations also flew in the face of the Jurgensen report's conclusions, which found that if domestic policies were incompatible with exchange-rate objectives, sterilized intervention was, at best, useless.

Support for the System's involvement with the Treasury in intervention was now clearly evaporating. At the 5-6 July 1989 FOMC meeting, those members opposed to foreign-exchange operations raised serious questions - some old, some new - about the operations. President Hoskins, for example, questioned Congress's reaction to System warehousing. This was an old question, but it met with new, rather specious, responses. Edwin Truman, Director of the Board's International Division, indicated that Congress had not questioned the operation, and he suggested that Congress implicitly approved warehousing in the late 1960s when it allowed the ESF to monetize SDR's with the System. Cross also noted that Congress allowed the ESF to monetize gold flows, and suggested that warehousing foreign exchange is a modern day equivalent (FOMC Transcripts 5-6 July 1989, 2). Yet, Congress explicitly authorized the monetization of gold and SDRs; Hoskin's point was that Congress had never explicitly authorized warehousing. Chairman Greenspan then suggested that warehousing might be a good thing for the System, since it allowed the Treasury to maintain their half of the now traditional 50/50 split on intervention (FOMC Transcripts 5-6 July 1989, 2). He did not appreciate that 
warehousing effectively left the System financing more than a 50 percent share, at least while the swap loan was on the System's books.

Cross went on to say that the recent U.S. interventions - as well as German and Japanese operations - had largely been discrete, undertaken through a commercial bank that acted as the Desk's agent. ${ }^{36}$ He claimed that "operating visibly was not really working very effectively," and that the discrete operations had been more effective. ${ }^{37}$ He went on to explain that when traders saw the Desk attempting to support the dollar, they "hit it quickly," selling dollars (FOMC Transcripts, 5-6 July 1989, p. 4). That is, the market bet against the Desk (see Chapter 5). Apparently, the market no longer viewed U.S. monetary authorities as having an information advantage. Instead, U.S. foreign-exchange sales had negative forecast value; that is, traders could make money by doing the opposite of what the System did.

Governor Angell thought that this secrecy potentially could confuse or mislead markets, but he also raised a new concern: Did the bank that acted as the agent for the Desk trade on priority information? Cross acknowledged that any bank with or through whom the Desk trades could do so. Governor Angell then suggested that market participants would always act in their own self interests, implying that they might routinely bet against the Fed if they thought it profitable (FOMC Transcripts, 5-6 July 1989, p. 5).

Governor Johnson then suggested that if the Federal Reserve stopped intervening and left intervention solely to the Treasury, it would not make any difference. If Cross were correct, if secret intervention worked better than overt operations, then the System could exit the program. Who would know? Greenspan seemed to agree; Cross equivocated, but Truman suggested that this would be the "worst possible world." The Federal Reserve would lose any influence that it had over the operations, and the Treasury might even stop the Federal Reserve from sterilizing the operations (FOMC Transcripts, 5-6 July 1989, p. 8).

Intervention to weaken the dollar continued until mid-October. The Desk sold \$2.6 billion German marks and $\$ 3.5$ billion Japanese yen, splitting the operations equally between the System's and the ESF's accounts. The FOMC raised the authorization of foreign currencies to $\$ 20$ billion and the authorization for warehousing to $\$ 10$ billion in late September. The System warehoused an additional $\$ 4$ billion worth of German marks for the U.S. Treasury, bringing the total to $\$ 7$ billion by the end of October 1989. Germany sold an addition $\$ 1.6$ billion.

The G7 had met in Washington D.C. in September 1989 and concluded that the continued appreciation of the dollar was incompatible with long-term fundamentals (Frankel 1994, p. 309). The FOMC began to face pressure to ease monetary policy as a means of offsetting the dollar's appreciation. This pressure only fanned the flames of concern about the conflict between intervention and monetary policy within the FOMC.

At the 3 October 1989 meeting, the debate about intervention reached a crisis stage. As noted, the Desk had been buying substantial amounts of German marks and Japanese yen. Governor Johnson forcefully questioned Cross about how the Desk or the G7 determined the dollar's fundamental equilibrium value. It was, of course, a question that Cross could not answer. Ever since Meese and Rogoff (1981, 1982, 1983), few economists had any faith in the ability of fundamentals-based models to forecast exchange rates at anything but a very low frequency. Johnson concluded: "Well, I realize there is a resistance to a lot of the [intervention] strategy here [among Committee members], but I think we ought to step up that resistance." (FOMC Transcripts, 3 October 1989, pp. 2-4). 
The President of the Philadelphia Federal Reserve Bank, Edward Boehne noted that the United States and other G7 countries were selling large quantities of dollars. Apparently referring to the Jurgensen Report, he suggested that world policymakers must be contemplating some other more fundamental policy changes, since it was widely understood that intervention had only a temporary effect when not supported by other policy moves (FOMC Transcripts, 3 October 1989, p. 4). Within the context of a narrow signaling channel, which Federal Reserve staffs understood, the massive intervention implied an easing of U.S. monetary policy.

Greenspan's subsequent comments could not have eased the committee's concern. He noted that the driving force behind recent interventions were the U.S. Treasury and the Japanese Ministry of Finance. Greenspan seemed to imply that the Treasury wanted monetary policy conducted within the G7 framework, meaning "essentially the G-7 would start to control monetary policy." Greenspan indicated that the Japanese Ministry of Finance and Undersecretary Mulford were both in favor of intervention and a lot of it. He did not think the System could - or should - bring intervention to an abrupt halt, but he would try to contain the damage, and if the dollar appreciated abruptly — the dollar had been appreciating - he would then try to convince Secretary Brady that intervention was futile (FOMC Transcripts 3 October 1989, p. 5).

Governor Johnson explicitly said that the recent sales of dollars conflicted with price stability. He noted that the public was beginning to believe the Federal Reserve's - and other central banks' - commitment to price stability. "For us to be countering that [the System's growing credibility] with this ridiculous approach just doesn't make sense; [it introduces] a potential doubt out there. If central banks continue to participate in this kind of strategy and show even a compromise on it, I think to some extent the markets are going to say this is a joke - in fact, they [the FOMC] are balancing the goals of the current account versus price stability." (FOMC Transcripts 3 October 1989, p. 6) Corrigan disagreed that the G7 was trying to supplant a price stability goal with a current-account objective, but Governors Johnson and Angell bluntly dismissed him.

After October 1989, U.S. intervention activity fell off, with the Desk making occasional one-day purchases of Japanese yen. In late February and March 1990, however, the Desk began a more forceful series of yen purchases. The Desk bought nearly $\$ 1.5$ billion worth of Japanese yen and \$200 million equivalent German marks. All of this, except a small amount of Japanese yen, was for the Treasury's account, because on 2 March 1990, the Federal Reserve unilaterally suspended its participation with the Treasury's interventions. Generally since 1980, with a few exceptions, the System and the Treasury had split interventions operations equally. In refusing to participate, the System informed the Treasury that the System account was near its intervention limits and that a comprehensive review of intervention was underway at the Board (FOMC Transcripts 27 March 1990, p.1).

\section{Task Force Papers \& Debate}

At their 22 August 1989 meeting, the FOMC formed a task force to undertake a comprehensive review of U.S. foreign-currency operations with an emphasis on System participation. The objective was to provide background information to help the Committee in their deliberations about intervention. The eleven Task Force papers, which the Board and the Federal Reserve Bank of New York completed for the 27 March 1990 FOMC meeting, covered all aspects of the System's involvement: its legal authority for foreign currency operations, the 
System's objectives, tactics, and operations, cooperation between the U.S. Treasury and the Federal Reserve System in this area, the various arrangements for financing intervention operations, its effectiveness and profitability, and intervention operations in other key developed countries. Although the papers did not espouse an overt position on intervention, Cross and Truman (9 March 1990), who summarized the work, took a firm position in favor of continued intervention.

Cross and Truman saw foreign-exchange-market intervention as providing the System with a policy tool that could influence exchange rates independent of monetary policy, despite providing no evidence to support such a claim. They did not describe intervention as a response to a market failure, but claimed instead that policy makers "no longer can expect that exchange rates will take care of themselves...in ways that U.S. policy would like or find acceptable with respect to conditions in the domestic economy." (p.12). ${ }^{38}$ They asserted that monetary policy could not ignore exchange rates and that the "Federal Reserve's active participation has been constructive both in terms of U.S. exchange rate policy and U.S. macroeconomic policy." (p.13) Moreover, Cross and Truman did not find evidence that inappropriate exchange-rate considerations or international (G7) understandings on exchange rates had subverted Federal Reserve monetary policy (p. 13), and they noted that the lack of empirical support for intervention did not mean that the operations were ineffective (p. 14). Finally, Cross and Truman advocated holding foreign-exchange balances because they enabled the United States "...to respond to exchange market developments without changes in U.S. monetary and other policies when such changes are not deemed appropriate for domestic objectives." (p. 18).

Yet, the emerging consensus of empirical studies offered little support for Cross and Truman's assertions. As part of the Task Force papers, Edison conducted a comprehensive review of the post-1982 intervention literature. A polished and published version appeared as Edison (1993). Edison (1993) found - once again - no new evidence in favor of a portfoliobalance channel, implying that intervention did not provide monetary policymakers with an independent instrument for affecting exchange rates. Sterilized intervention could at best have a short-run effect through an expectations channel. In addition, evidence as to whether coordinated intervention was more effective than unilateral intervention appeared disturbingly inconclusive. Bordo and Schwartz (1991), Humpage (1988), and Obstfeld (1990) concluded that the intervention episodes since 1985 were, by and large, unsuccessful in terms of their effects on dollar exchange rates.

\section{Debate Renewed}

If the Task Force papers were meant to assuage FOMC participants' concerns about intervention, they were a dismal failure. Since the beginning of 1989, at a time when the FOMC maintained a tight monetary policy, the Desk had purchased over $\$ 24$ billion equivalent in foreign exchange, with roughly half for the System's account, through the largest, most protracted operations ever, and all at the Treasury's initiative. Intervention in this magnitude, as President Boehne noted, was not consistent with calming market disorder but smacked of exchange-rate manipulation (FOMC Transcripts 27 March 1990, p. 47).

The huge volume of intervention also was affecting the quality of the System's balance sheet. Foreign exchange was becoming an extraordinary share of Federal Reserve assets, implying that a growing amount of an inferior form of collateral-foreign exchange rather than Treasuries_-backed the System's reserves. To the extent that the Desk held an open position, 
these foreign-exchange reserves exposed the System to valuation losses should the dollar appreciate. Federal Reserve Bank of Richmond President Robert Black suggests that there were at least two dangers associated with holding a large portfolio. One peril is that the System's credibility with respect to price stability would be undermined because the market might expect the System to ease policy to avoid a dollar appreciation and huge losses on its portfolio. The other threat is that Congress might try to persuade the System to ease policy to avoid big losses (FOMC Transcripts 27 March 1990, p. 55).

Governor Johnson worried that this heavy intervention could create uncertainty in the open market, which could complicate the System's ability to sterilize the interventions. Johnson, who did believe that sterilized intervention could sometimes be effective in the short-tointermediate term, wanted the FOMC to cut off the intervention at some point and to refuse to warehouse foreign exchange for the Treasury. Markets, he claimed, would understand (FOMC Transcripts 27 March 1990, pp. 49-55).

Chairman Greenspan now portrayed the Federal Reserve as the voice of reason in the whole affair. He feared that if the System continued to unilaterally refuse to intervene, it would lose influence over the Treasury's intervention activities; he was "quite fearful of what they might do if we weren't there to harass them toward some degree of sensibleness." He viewed the current Treasury and most previous Treasuries as "heavy interventionists." (FOMC Transcripts 27 March 1990, pp. 46-57). President Hoskins, however, turned this argument on its head, arguing that intervention gave the Treasury influence over the Federal Reserve. Hoskins agreed that the System could sterilize transactions, but contended that under current arrangements, the Treasury nevertheless influenced the size of the System's portfolio (FOMC Transcripts 27 March 1990, p. 49). President Corrigan, in support of the Chairman, argued that not only would the System lose power over the Treasury, but the System would lose international stature, notable in the G7 (FOMC Transcripts 27 March 1990, pp. 57-59).

After a lengthy discussion, Chairman Greenspan noted that the "vast majority" of the FOMC seemed in favor of continued System participation with the Treasury in intervention. He agreed to confront the Treasury about the recent size of intervention, but he noted that if the System confronted Treasury about intervention in general, it would surely lose in Congress. Greenspan then recommended that the FOMC increase the warehousing limit to $\$ 15$ billion and the overall net open position to $\$ 25$ billion. He agreed to Johnson's request to refuse to participate in an intervention designed to drive the dollar down (FOMC Transcripts 27 March 1990, pp. 69-70).

Some FOMC members, however, wanted to set a limit on intervention. President of the St. Louis Federal Reserve Bank Thomas Melzer then suggested that the System inform the Treasury that the current intervention amounts were a limit and that the FOMC did not want to see more intervention. Greenspan, however, thought that the Treasury might interpret such a warning as a threat, and he again warned that the System could not prevail against the Treasury in this matter (FOMC Transcripts 27 March 1990, pp. 70-71). Hoskins agreed that the System should participate with the Treasury to some degree, but objected to the current size of the System's involvement— $\$ 25$ billion. He recommended a "Treasury/Fed Accord II" before the position becomes much larger (FOMC Transcripts 27 March 1990, pp. 77).

At this meeting, the FOMC voted to increase the authorization for foreign exchange from $\$ 21$ billion to $\$ 25$ billion effective immediately. Three members dissented: Governor Angell, 
President Hoskins, and President LaWare. The FOMC also voted to increase the authority for warehousing from $\$ 10$ billion to $\$ 15$ billion, and the same three individuals dissented. The Treasury's warehousing reached \$9 billion in June 1990.

At roughly this same time, however, the Treasury's attitude about foreign-exchange intervention inexplicitly seemed to change. The extent to which complaints within the FOMC influenced the Treasury's perception of intervention is not clear. Nevertheless, on an 11 April 1990 conference call with FOMC participants, Chairman Greenspan reported how Treasury Secretary Brady recently told the G7 that after spending $\$ 40$ billion to defend the Japanese yen, he (Brady) had concluded that, "It just doesn't work.",39 (FOMC Transcripts 11 April 1990, p.1) Brady would no longer offer the Japanese support for the yen. The Economic Report of the President for 1991 was the last one - at least through 1996 - that mentioned foreign-exchange intervention.

The Treasury also took steps to ease System concerns about its balance sheet. Beginning on 29 May 1990, the Desk began quietly selling German marks from the Treasury's account. The objective was to sell $\$ 2$ billion equivalent marks by July 1990 and to use the dollar proceeds of those sales to buy back German marks that the Treasury had warehoused with the Federal Reserve. The Desk sold $\$ 1$ billion equivalent of these marks in the market and sold $\$ 1$ billion equivalent marks off-market to a central bank (Bulletin October 1990, pp. 821-822, FOMC Transcripts Appendix p. 5). The Treasury currently had $\$ 9$ billion warehoused with the System, but by July 1990 it reduced that amount to $\$ 7$ billion. The ESF also began buying back Special Drawing Right (SDR) certificates from the System, and selling the SDRs to IMF members that needed them to make payments to the IMF. The ESF then used the acquired dollars to draw down warehousing commitments to the Federal Reserve. By the 13 November 1990 FOMC meeting, the amount warehoused had dropped to $\$ 2.5$ billion.

As intervention abated, President Hoskins, who viewed price stability as the sole objective of monetary policy, now took aim at its ancillary mechanisms: warehousing and swap lines. He suggested lowering the warehousing authorization from $\$ 15$ billion. Hoskins also questioned why the System offered Mexico a swap line (see below). He noted that the other countries had AA (or better) ratings on their debt and widely convertible currencies. The swaps to Mexico were like foreign aid or a loan and did not match the traditional purpose for the swap lines. At the 18 December 1990 FOMC meeting, Hoskins questioned the renewal of the entire swap mechanism since the System now held a substantial portfolio of foreign-exchange reserves (FOMC Transcripts 18 December 1990, p. 1). At the 5 February 1991 meeting, Cross recommended lowering the authorization for warehousing from $\$ 15$ billion to $\$ 10$ billion, noting that the Treasury never exceeded $\$ 9$ billion. President Hoskins argued that if the FOMC supported this new limit - instead of letting the facility run dry - it was essentially endorsing the idea of warehousing for the Treasury. Hoskins viewed warehousing as a loan to the Treasury, which violates the principle of central bank independence. The President of the Kansas City Federal Reserve Bank Roger Guffey asked for a \$5 billion limit (FOMC Transcripts 5 February 1991, pp. 3-4). The FOMC would not lower the authorization to $\$ 5$ billion for another year.

At the 26 March 1991 FOMC meeting, with many FOMC participants attempting to roll back the System's authorization for holding foreign exchange and, therefore, its commitment to intervention, Cross championed holding a large portfolio. At that time the System held $\$ 17.8$ billion equivalent German marks and $\$ 6.9$ billion equivalent Japanese yen. A large portfolio, Cross claimed, gave the System more flexibility when it intervened. ${ }^{40}$ With a portfolio of funds, 
the System need not depend on foreign sources of foreign exchange. Moreover, the market knew that the System had substantial funds for intervention, which reduced destabilizing speculation and, therefore, lessened the chances that the System would have to use them. He noted that the portfolio did expose the System to exchange-valuation losses, but this ultimately affected only the profits that the System returned to the Treasury. He claimed that "if we simply adopted a conscious policy of getting rid of a substantial part of our reserves, it seems to me that that could be seen by the market and by foreign officials and by the general public as a move by the United States toward withdrawal of its role in international responsibilities and its role in helping to maintain the stability and smooth functioning of the [international financial] system." (FOMC Transcripts 26 March 1991, pp. 8-9).

Governor Mullins asked what the conceptual basis was for determining the appropriate level of reserve holdings, but Cross did not have a good reply. Chairman Greenspan noted that borrowing was an alternative. President Hoskins then recalled that in late 1987 and early 1988, when concern over intervention started, the System held reserves of only about $\$ 10$ billion. At the time, most FOMC participants thought that intervention was of little use, but agreed that holding some reserves signaled international cooperation and "show[ed] the flag." Hoskins contended that there was no rationale for accumulating reserves since that time, and he cautioned that the exposure (the dollar was now appreciating, forcing losses on the portfolio) and continued warehousing could create problems for the System.

In early 1991, reducing the System's portfolio through sales of foreign exchange was difficult because the dollar was appreciating. At a 24 June 1991 conference call, Cross revealed that the United States had worked out a plan with the Bundesbank to reduce U.S. holdings of German marks by DM10 billion. The transactions would be at market rates, but would be conducted off-market. The first exchange of DM4 billion was scheduled for 25 June 1991. Six more exchanges of DM1 billion each would follow over the next six months, with each priced at forward rates prevailing on 25 June 1991. Sixty percent of the marks came from the System's portfolio and 40 percent from the Treasury's. The transactions would exceed the daily and intermeeting limits on intervention, and were cleared with the Chairman and with the Subcommittee in accordance with the procedural instructions. Following a question from Hoskins, Cross indicated that this arrangement implied no future obligation to intervene. Hoskins continued to recommend lowering the authorization to hold foreign currencies (FOMC Transcripts 24 June 1991, pp. 3-6).

\section{Renewed Conflicts with the Treasury}

Despite the Treasury's changing views on intervention, the United States continued to intervene after mid-1990, although the amount and frequency of these operations declined substantially. Often the United States undertook the operations largely out of a spirit of cooperation with its allies and less out of a concern for exchange rates. By and large, the FOMC seemed content with the operations, until August 1992.

That summer, the dollar fell sharply against the German mark as interest rate spreads between Europe and the United States widened substantially. In July 1992, for example, the Bundesbank's discount rate reached $8.75 \%$ while the Federal Reserve's discount and federal funds target rates were lowered to $3 \%$ and $3.25 \%$ respectively. The mark moved to the top of the ERM while the Italian lira and British pound reached the bottom. Markets expected a realignment of the ERM, especially given that the Danes had rejected the Maastricht treaty. 
Although the dollar fell against the German mark, the United States did not view this as a dollar problem, one requiring heavy concerted intervention with the Europeans. The United States did, however, intervene in concert with the Europeans on three occasions in late July and early August when the market seemed disorderly. The Desk's sales of German marks were fairly large, totaling $\$ 800$ million equivalent, and they seemed to surprise private-market participants. Federal Reserve Bank of New York President McDonough claimed they were successful, although the dollar continued to depreciate against the mark through August. On 11 August 1992, however, Treasury Secretary Brady called for lower interest rates, which caused the dollar to fall and appeared to sabotage the intervention (FOMC Transcripts 18 August 1992, McDonough Appendix, pp. 1-7).

At the 18 August 1992 FOMC meeting, questions arose again about the purpose of the intervention and about its implication for monetary policy credibility, since it involved buying dollars when the FOMC was easing. McDonough claimed the Treasury was interested in managing an exchange rate, but that the Desk was only interested in maintaining orderly markets (FOMC Transcripts 18 August 1992, p.2). Then Atlanta President Robert Forrestal captured the sentiment against intervention within the FOMC (FOMC Transcripts 18 August 1992, p. 3):

"I've heard the rationale of disorderly markets, but I feel constrained to say that I was extremely surprised at this intervention, particularly the second and the third operations. Of course, I would respect the judgment of the Desk and Bill [McDonough] with regard to whether the markets were in fact disorderly. But we've had extensive discussions over the last year or so in the Committee on the effectiveness of sterilized intervention, and I thought it was the sense of this group that, unless we were going to follow intervention with some kind of substantive monetary policy move, intervention was not the policy of this committee. What really compounds the problem with respect to our credibility is having intervention and then having that followed by the Secretary's statement that he's looking for lower interest rates. That to me made us look extremely silly, to put it lightly."

Chairman Greeenspan attempted to put the operation in a better light, noting that "we're all pretty much aware that there is very little intervention can do in and of itself to affect the average of any exchange rate over a particular period of time." But, he contended that on occasion the market breaks down and "the evidence does suggest that when that occurs we in fact can affect the market. ...markets feed on themselves, get out of hand, and sometimes create some degree of instability." (FOMC Transcripts 18 August 1992, p. 5)

On 21 and 24 August 1992, as the dollar moved lower against the German mark, the U.S. Treasury asked the Desk to arrange a coordinated intervention. The Desk advised against the intervention, but the Treasury insisted. After consulting Chairman Greenspan, the Federal Reserve decided that it had to act in concert with the Treasury because the market might learn that the Treasury and System were at odds over intervention at a time when the dollar was low relative to the German mark (FOMC Transcripts 6 October 1993, McDonough's Statement Appendix pp.1-2.). Essentially the Federal Reserve had little choice in the matter, if the Treasury wanted to intervene. None of the subsequent interventions seemed successful.

The disintegration of the European Monetary System had prompted these interventions. The EMS was created in 1979, but the member countries had undertaken no currency 
realignments since January 1987, despite substantial differences in their economic performances. After easing fiscal and monetary policy to facilitate the re-unification of the country, Germany had recently been tightening to avoid the inflationary consequences of its earlier policies. German interest rates were very high, which caused difficulties for some EMS countries that were experiencing weak economic growth. Amid heavy speculation, Italy devalued the lira on 13 September 1992. On 16 September 1992, Britain and Italy pulled out of the ERM, while Ireland, Spain, and Portugal imposed exchange controls (FOMC Transcripts 6 October 1992, McDonough Appendix, pp. 1-8). The Germans did not want to hold the ERM together; they wanted more flexibility to pursue domestic-policy objectives (FOMC Transcripts 6 October 1992, p. 2).

The focus then shifted to the Japanese yen. On 27 April 1993, the United States sold \$200 million equivalent yen in an operation largely designed to show cooperation with the Bank of Japan rather than a commitment to intervention. The yen was under strong upward pressure, and according to Margaret Greene, Manager of the Foreign Desk, "market participants were doubtful that the Japanese authorities could be effective until other governments signaled they, too, were concerned about the movement in the exchange rate." The market expected that upcoming trade talks between the United States and Japan would be confrontational and the dollar depreciated sharply against the yen. At the Treasury's suggestion the Desk intervened openly in several rounds, during the day. The amounts were split evenly between the Treasury's and the System's accounts (FOMC Transcripts 18 May 1993, Greene Appendix pp. 3-4).

Chairman Greenspan offered that the recent intervention was a response to spillover effects from the exchange market to other financial markets, which implied a lack of confidence in the dollar. The FOMC had earlier suggested that such a spillover was a necessary condition for intervention (FOMC Transcripts 18 May 1993, pp. 4-5). Further interventions against Japanese yen followed in late May, early June, and August 1993, although they remained fairly isolated events.

On 29 April and 4 May 1994, the Desk sold both German marks and Japanese yen from both the System's and Treasury's accounts. These operations were fairly large, totaling \$ 0.7 billion and $\$ 1.3$ billion, respectively. Federal Reserve Bank of Cleveland President Jerry Jordan asked what the participants in the operation intended to signal through the intervention, and he noted Germany's lack of enthusiasm for the operation. (Germany bought only \$250 million dollars on a single day, whereas Japan bought $\$ 1.6$ billion on consecutive days between 28 April and 4 May. $)^{41}$ The object according to Peter Fisher was to communicate with both inter-bank traders and the broader financial markets that the dollar had gone beyond levels justified by fundamentals and to underline a change in policy (FOMC Transcripts 17 May 1994, pp. 1- 4).

The Desk again sold \$1.3 billion German marks and \$1.3 billion Japanese yen in early November 1994. Japan participated, buying nearly \$1.7 billion, but Germany remained out of the market. At the 15 November 1994 FOMC meeting, Federal Reserve Bank of Richmond President Broaddus argued against intervention because it must interfere with the System's monetary-policy independence:

"As you said, Mr. Chairman, it is now widely agreed that sterilized intervention doesn't have any sustained impact on exchange rates unless it sends a signal that we are going to follow it up with a monetary policy action. This implies, for me at least, and this is really the heart of the matter, that it is 
not really possible for the Fed to maintain a truly independent monetary policy for an extended period of time while following the Treasury's lead on foreign exchange policy. Now, of course, in reality the way I see this is that we have maintained our independence by not making a commitment to follow interventions with monetary policy actions. But that's not a perfect situation either." (FOMC Transcripts 15 November 1994, p. 49).

In 1995, the Federal Reserve Bank of Richmond articulated the case against intervention (Broaddus and Goodfriend 1996). ${ }^{42}$ Although most of the core arguments were well known to FOMC participants, Richmond's perspective seemed fresh because the authors developed the exposition more completely and clearly than heretofore had been the case. They focused on the connection between intervention and monetary-policy credibility. Sterilized intervention and the institutions associated with intervention damaged the Federal Reserve's credibility with respect to price stability, they claimed, because Congress had never statutorily mandated price stability as the Fed's sole - or even chief_- policy goal. The System's credibility with respect to price stability was purely reputation-based. Such credibility is hard to acquire and is inherently fragile. Central bank independence - keeping the System free of political influence-is the sine qua non of reputation-based credibility.

Although sterilized intervention had no direct impact on the monetary base, the Richmond exposition argued that economists and policy makers understood - at least since the Jurgensen Report - that such operations were ineffective unless monetary policy supported them. Participation in sterilized foreign exchange operations under the Treasury's leadership, often within G7 forums, must then create uncertainty about the relative weights that the System gave to its price and exchange-rate objectives, especially — as often was the case-when these two objectives conflicted.

Richmond also argued that the System's portfolio of foreign exchange-acquired through intervention, warehousing, or foreign loans - resulted in a substitution of foreign securities on the System's books for U.S. Treasury securities. By holding these securities, the Federal Reserve was extending credit to foreign governments and exposing its balance sheet to market risk and sometimes to credit risk. The decision to put funds at risk by extending credit to foreign governments was a fiscal policy action that Congress - not the Federal Reserve - should undertake (see also Goodfriend 1994). The Federal Reserve's engagement in these fiscal operations skirted the Congressional appropriations process, avoided Congressionally mandated public-debt limits and, consequently, was a misuse of the System's off-budget status. Congress had put the System outside of the appropriations process to safeguard its independence. If any of these foreign-exchange operations go wrong, however, the Federal Reserve might face Congressional criticism and actions that could damage the System's independence.

By 1994, many FOMC participants were leaning hard towards very little involvement. McDonough suggested that withdrawing from intervention or not renewing the swap lines was isolationist, and would have a big impact (FOMC Transcripts 15 November 1994, p. 52). Governor Kelly suggested that it would signal a lack of financial management and arrogance on the part of the Fed to thumb its nose at the Treasury and the Government, and it might get Congress involved (FOMC Transcripts 15 November 1994, p. 53). In contrast, Federal Reserve Bank of Minneapolis President Stern agreed that the cost of intervention was an erosion of credibility (FOMC Transcripts 15 November 1994, p. 54). President Broaddus then dissented on a vote to renew the swap lines. 
The System intervened occasionally in 1995, but after August of that year, U.S. intervention effectively ended. The System bought $\$ 833$ million equivalent Japanese yen on 17 June 1998 in an isolated transaction and bought \$1.3 billion euros on 22 September 2000. Neither operation was successful. Since that time, the System has eschewed intervention.

\section{Analysis of Post-Louvre Intervention.}

The U.S. interventions during the early 1990s were again largely ineffective at moving dollar exchange rates in a manner consistent with calming market disorder. Only about 64 percent of the intervention successfully altered exchange rate movements.

Over the 2,318 business days between 2 May 1988 and 19 March 1997, the United States sold German marks on 44 days and bought German marks on 111 days (see table 4). Twentytwo of the U.S. sales of German marks were associated with same-day dollar appreciations, and 54 of the U.S. purchases of German marks were associated with same-day dollar depreciations. In both cases, the observed number of successes was not statistically greater than the number of successes that we would expect to observe given the variable nature of day-to-day exchange-rate changes. Likewise, six of the 44 U.S. sales of German marks were associated with a slowing in the pace of the dollar's depreciation and 17 of the U.S. purchases of German marks were associated with a slowing in the pace of the dollar's appreciation. Again, however, in neither case was the success count statistically different than the number that we would randomly anticipate. U.S. intervention against German marks was not obviously successful at achieving common, measurable outcomes consistent with calming disorderly markets.

Over the same time interval, the United States sold Japanese yen on 31 days and bought yen on 87 days. Fifteen of the U.S. sales of Japanese yen were associated with a same-day dollar appreciation, and 38 of the U.S. purchases of Japanese yen were associated with a same-day dollar depreciation. As with the German mark, in both cases, the observed number of successes was not statistically different than the number of successes that we randomly anticipate. Eight of the U.S. sales of Japanese yen were associated with a moderation in the pace of the dollar's depreciation, and 14 of the U.S. purchases of Japanese yen were associated with a moderation in the pace of the dollar's appreciation. Both of these success counts exceeds the amount one would predict given the variable nature of daily exchange-rate movements, but only the formereight out of 31 sales of yen - is statistically greater than the expected amount.

\section{Swaps, Warehousing, and the Mexico Peso Crisis}

Support for foreign-exchange-market intervention within the FOMC waned after the U.S. stock-market collapse in 1987 because the committee increasingly viewed such operations as inconsistent with a credible commitment to price stability. As noted above, this was a fairly new concern, one that emerged as views about the role for monetary policy changed. Traditionally, FOMC participants worried that the institutions to support foreign-exchange-market intervention - warehousing foreign currencies for the Treasury and swap lines - could threaten System independence if Congress came to view their use as a means of financing foreign-policy initiatives outside of the Congressional appropriations process. Yet this problem had never seriously confronted the FOMC, until the Mexican peso crisis of 1995. Then the import of these traditional concerns crystallized. 


\section{Mexican Swaps}

The Bank of Mexico first joined the Federal Reserve System's swap network along with the central banks of Denmark and Norway in May $1967 .{ }^{43}$ Mexico had maintained a reciprocal swap line with the U.S. Treasury since 1965, which itself replaced a much older agreement. During the 1960s, Mexico had experienced strong real economic growth, reasonable price stability, external balance, and ready access to international financial markets. Extending the swap line to Mexico did not seem unusual, given the size of the Mexican economy - then larger than Austria or Denmark - and given the close economic ties between Mexico and the United States. At the time, U.S. banks held approximately $\$ 1.3$ billion in claims on Mexico (Maroni 1994b).

The FOMC expanded the Mexican swap line three times during the 1970s, bringing the regular swap line to $\$ 700$ million by 1994 . The growth of the regular swap line paralleled the expansion of Mexico's foreign and domestic economic activity and a sharp rise in U.S. bank claims on Mexico. In addition, the System created two special temporary swap lines prior to 1994, which were associated with multilateral debt stabilization packages. The first, on 28 August 1982, gave Mexico a $\$ 325$ million credit line to deal with its international debt crisis. The second, on 14 September 1989, offered Mexico $\$ 125$ billion to aid in restructuring the country's foreign bank debt. In addition, in 1988 and 1993, Mexico and the United States consider additional short-term debt facilities, including an extension of the System's swap lines, but both parties mutually terminated these initiatives before they came to fruition (Maroni 1994b).

Between 1990 and 1994, inflation in Mexico greatly exceeded inflation in the United States, a situation that fostered a peso depreciation. Beginning in November 1991, however, Mexico maintained the peso-dollar exchange rate within moving bands that limited the pace of the peso's deprecation against the U.S. dollar. The Mexican government had negotiated the rate of the peso's depreciation as part of a wage negotiation with local unions. This arrangement left the peso substantially overvalued relative to the dollar on a purchasing-power-parity basis and produced a large and growing current-account deficit. Foreign financial inflows associated with NAFTA helped to finance Mexico's resulting deficit, which reached 8\% of GDP by 1994. Still, Mexican monetary authorities drew down their foreign-exchange reserves in managing the exchange rate (Maroni 1994a).

In early 1994, after concluding NAFTA and in anticipation of making the Bank of Mexico independent of the Ministry of Finance, Mexico requested a permanent increase in its swap lines with both the Federal Reserve and the U.S. Treasury. At the time, the peso was coming under strong downward pressure in part because an uprising in Chiapas raised investors' concerns. Moreover, peso devaluations had often followed Mexican elections and one was due in August 1994. Mexico attempted to assuage investors' concerns and avoid a peso depreciation by offering dollar-index debt (Tesobonos) instead of peso debt (Cetes).

The proposal for an increase in the Mexican swap lines rekindled a debate about swaps at the 22 March 1994 FOMC meeting. System swaps were intended to finance interventions aimed at calming "disorderly markets," but Mexico presented some unusual considerations. Mexico had drawn on its regular swap lines 16 times prior to 1994. Some of these past drawings had merely provided temporary window-dressing for its foreign exchange reserves and some had offered funds in anticipation of financial-market turmoil prior to Presidential elections. 
Moreover, Mexico currently seemed to be defending an unviable peg. Many FOMC participants - notably Alfred Broaddus, President of the Federal Reserve Bank of Richmond and Jerry Jordan, President of the Federal Reserve Bank of Cleveland — did not consider such uses as being consistent with calming disorderly markets. Chairman Greenspan, who claimed a philosophical allegiance with Broaddus and Jordan, nevertheless again argued in favor of cooperating with the Treasury (FOMC Transcripts 22 March 1994, pp. 2-15).

\section{Crisis and Questions about Appropriate Use}

Following the 24 March 1994 assassination of Mexican presidential candidate Luis Donaldo Colosio the United States provided a temporary increase in the Mexican swap lines to $\$ 6.0$ billion, split evenly between the System and the ESF. ${ }^{44}$ Canada offered a $\$ 730$ million swap line. On 26 April 1994, Canada, Mexico, and the United States made these temporary swap lines permanent as part of NAFTA. ${ }^{45}$ All of the lines were reciprocal. Drawings on the Mexican swap line would require FOMC approval, and Mexico must provide collateral to the Federal Reserve Bank of New York for swap drawings in excess of \$1 billion. The agreement also established a formal consultative mechanism among the NAFTA countries, which helped authorities monitor economic developments in Mexico. ${ }^{46}$

Mexico must have thought that the mere existence of the swap lines would calm investors' fears, since the country did not immediately draw on these lines. The Bank of Mexico continued to defend the peso exchange rate out of its official reserves. Speculators, however, had a one-way bet; they knew the direction that the peso would follow, only the timing was uncertain. After the election, the Bank of Mexico committed large amounts of reserves to defending the peso and investor concerns increased. On 20 December 1994, Mexico, with its dollar reserves depleted, devalued the peso and two days later allowed the peso to float. This action precipitated a financial crisis. In response to the crisis, both the ESF and the System temporarily increased each of their swap lines with Mexico to $\$ 4.5$ billion, bringing the total facility to $\$ 9.0$ billion.

The Clinton administration asked the U.S. Congress to provide $\$ 40$ billion in loan guarantees to Mexico, but Congress refused this request. The U.S. Treasury, however, had already made contingency plans for providing financial aid to Mexico in 1993, when it feared that Congress might defeat NAFTA and set off financial flight from Mexico. That plan envisaged offering Mexico a $\$ 12$ billion credit line with $\$ 6$ billion coming from the United States and $\$ 6$ billion coming from Europe. Half of the U.S. commitment would come from an increase in the Federal Reserve's swap line with Mexico from $\$ 700$ million to $\$ 3$ billion (see Hetzel 2008, p. 208). This time, the ESF would provide Mexico both short-term and mediumterm swaps and possibly loans and loan guarantees for a total package of up to $\$ 20$ billion dollars. The ESF currently held only $\$ 5$ billion in liquid dollar assets and $\$ 19.5$ billion in German marks and Japanese yen (FOMC Transcripts 31 January \& 1 February 1997, pp 59-75, pp. 117-144). To acquire the necessary dollars, the administration asked the System to warehouse up to $\$ 20$ billion in foreign exchange. (The FOMC had recently pared the System's authorization for warehousing to $\$ 5$ billion.) Of that amount, the Treasury would use $\$ 6$ billion to back the System's own swap lines with Mexico, leaving the ESF \$14 billion (FOMC Transcripts 31 January \& 1 February 1995, p.122). The System would warehouse German marks and Japanese yen, not Mexican pesos. Truman warned that the warehousing could extend for ten years (FOMC Transcripts 31 January \& 1 February 1995, p. 124-25). 
The Federal Reserve would also provide Mexico with the regular \$3 billion swap line and with an additional $\$ 3$ billion special swap line. Mexico could draw on both lines for a 12 month period; the drawing would roll over every three months for up to 12 months. At the latest, final payments would be due before 31 January 1997. The Treasury, however, would have to take the System out of any loan after 12 months, implying that the System assumed no credit or market risks. As the Bank of Mexico paid off each of the drawings, the special swap would disappear. While the Treasury backed up the System, Mexican oil revenues acting as collateral backed up the Treasury.

At the 31 January and 1 February 1995 FOMC meeting, Governor Melzer argued that the Federal Reserve should only participate in the swap loans to Mexico and warehousing with Treasury if the situation represented a systemic risk to the U.S. financial system. Otherwise, the Treasury should undertake the operations alone through the appropriations process. He worried that Congress, which was not in favor of a Mexican bailout, might view warehousing on this scale as a subversion of its will. Meltzer also implied that increasing the warehousing to \$20 billion might set a precedent that would continue beyond the Mexican situation when the Treasury might again be interested in intervention. Moreover, if the System held additional German mark and Japanese yen securities on its books and sold domestic securities to sterilize the transactions, it would violate rules about the amount of appropriate collateral to back Federal Reserve notes outstanding. Meltzer recalled this being a problem when the System was warehousing \$9 billion (FOMC Transcripts 31 January \& 1 February 1995, pp. 117-145). Governors Meltzer and Lindsey voted no on the measure to increase the swap line with Mexico and on the measure to increase the appropriation for warehousing with the Treasury. President Broaddus and President Jordan, who also opposed the action, were not then voting members of the FOMC.

On 31 January 1995, the Clinton administration announced a $\$ 47.8$ billion Mexican aid package, which included $\$ 20$ billion from the United States, $\$ 17.8$ billion from the IMF in 18month stand-by credits, and a $\$ 10$ billion line of credit with the BIS. The FOMC provided $\$ 6$ billion by extending the swap lines and increased its authorization for warehousing to $\$ 20$ billion.

That the swap and warehousing arrangements were a fait accompli did not silence debate among FOMC participants. At the 28 March 1995 FOMC meeting, President Broaddus, after reading Truman's memo on the System's legal authority for warehousing, objected to the operation. Broaddus contended that warehousing was a fiscal operation. "By that I mean that in the end the warehousing operation has exactly the same final effect as if Congress authorized the Treasury or the ESF to purchase the foreign exchange and fund the purchase by issuing additional debt in the market. The only difference ... is that the usual Congressional appropriations process is circumvented, and the purchase does not show up in the budget." (FOMC Transcript 28 March 1995, p. 4) The fiscal nature arose because in the process of sterilizing the Treasury's use of the dollars obtained from warehousing, the System issued Treasury securities from its portfolio. Broaddus noted that the System was "off-budget," and he worried that warehousing and the recent swap arrangements with Mexico suggested that the System was financing operations beyond the Congressional budget process that the American people might not favor. He worried that this could raise Congressional ire and could threaten System independence (see Broaddus and Goodfriend 1996, and Goodfriend 1994). 
Greenspan responded: "On the issue of how to deal with the Treasury in this government, as fiscal agent we involve ourselves in various types of support for the Treasury and that does in some sense impinge on the independence of this institution. The trouble, unfortunately, is that we cannot be fully independent because there is only one government and there is an element here trying to draw the line. I think we are somewhat uncomfortable about the warehousing facility. I think we are all uncomfortable about our own swap line facility, and are in opposition to the initiatives of the Treasury. But we also recognize that the central bank has very broad responsibilities to ensure the safety and soundness of the financial system." (FOMC Transcript 28 March 1995, p. 5). The potential for spillover to U.S. financial markets became the justification for the action.

Truman also responded to Broaddus, arguing that the Treasury could undertake warehousing with the market - e.g., with banks or other financial institutions - and consequently, Federal Reserve warehousing did not represent a breach of the fiscal authority of Congress. Truman went on to say that the System had changed the warehousing arrangements "so that it is now very clearly an arms-length, market-related transaction." Truman's observation, however, did not sway anyone. If the Treasury could undertake warehousing with the private sector, they should do so and leave the Federal Reserve out of the operations (FOMC Transcript 28 March 1995, p. 5-6).

In the end, the ESF never warehoused foreign currencies with the System during the Mexican peso crisis. The warehousing authorization reverted to \$5 billion in 1996 and has remained there ever since that time. The last time that the ESF warehoused foreign exchange with the System was in 1992.

Mexico drew as much as $\$ 1.5$ billion on its swap lines with the System, but paid this amount completely down by January 1996. The System decided to eliminate all of its swap lines when the euro came into existence in December 1999, except for on-going swap lines with its NAFTA partners, Canada and Mexico. Nevertheless, swap lines now have a long history and are easy to put in place, as we saw during the recent financial crisis of 2007 and 2008 and the European debt problems of 2010.

\section{Conclusion}

The United States stopped intervening in the foreign-exchange market primarily because FOMC participants believed that intervention, and the institutional arrangements associated with it, undermined their ability to establish and to maintain a credible commitment to price stability. Absent an exploitable portfolio-balance mechanism, sterilized intervention did not offer policy makers a means for systematically determining exchange rates independent of monetary policy. By the mid-1980s, support for the portfolio-balance mechanism had evaporated. By then, most observers understood that for intervention to have anything more than a fleeting effect on exchange rates, monetary policy had to back it up, but this essentially put the cart before the horse from the FOMC's perspective. Exchange rates often responded to the overall thrust of U.S. monetary policy, so intervening to offset them could contravene the very policy that set them in motion while damaging credibility. This became a critical problem in the late 1980s and early 1990s as the FOMC attempted to bring inflation expectations - then hovering in a 3 percent to 4 percent range - to a level more consistent with their perceptions of price stability.

In addition, FOMC participants objected to many of the institutional arrangements for intervention because they threatened the System's independence and, in doing so, also 
compromised the credibility of monetary policy. The U.S. Secretary of Treasury had primary responsibility for U.S. foreign-exchange intervention. He often formulated intervention policy as an adjunct to macroeconomic policy coordination within the G7 framework. In doing so, he occasionally recommended changes in monetary policy. The System could easily fend off calls for interest rate cuts, but to refuse to undertake sterilized intervention was another matter altogether. Although the System had independent authority for intervention, even such strong chairmen as Paul Volcker and Alan Greenspan were extremely reluctant to exercise their autonomy for fear of appearing to undermine an administration policy. The System also worried that warehousing foreign exchange for the Treasury and extending swap loans at the Treasury's behest to developing countries threatened its independence because Congress might view either of these arrangements as contravening the appropriation process. The Mexican crisis brought such issues to the fore.

Because of these concerns, the United States essentially stopped intervening by the mid1990s, but the U.S. policymakers never dismissed intervention as completely ineffectual. Many FOMC participants accepted that the foreign-exchange market could sometimes become disorderly and that foreign-exchange intervention might offer a means of calming market disorder. Like much of the empirical literature, we have shown that intervention does sometimes affect the exchange-rate movements. Specifically, we have shown that the capacity of intervention to moderate exchange rate movements is greater than random, but, at best, only about one in five interventions are successful on this score. In the late 1980s and early 1990s, the FOMC objected to the frequent and heavy interventions then underway, primarily because they threatened monetary policy credibility, not because they rarely worked. 
Figure 1: U.S. Intervention against German Marks April 1981 - March 1997

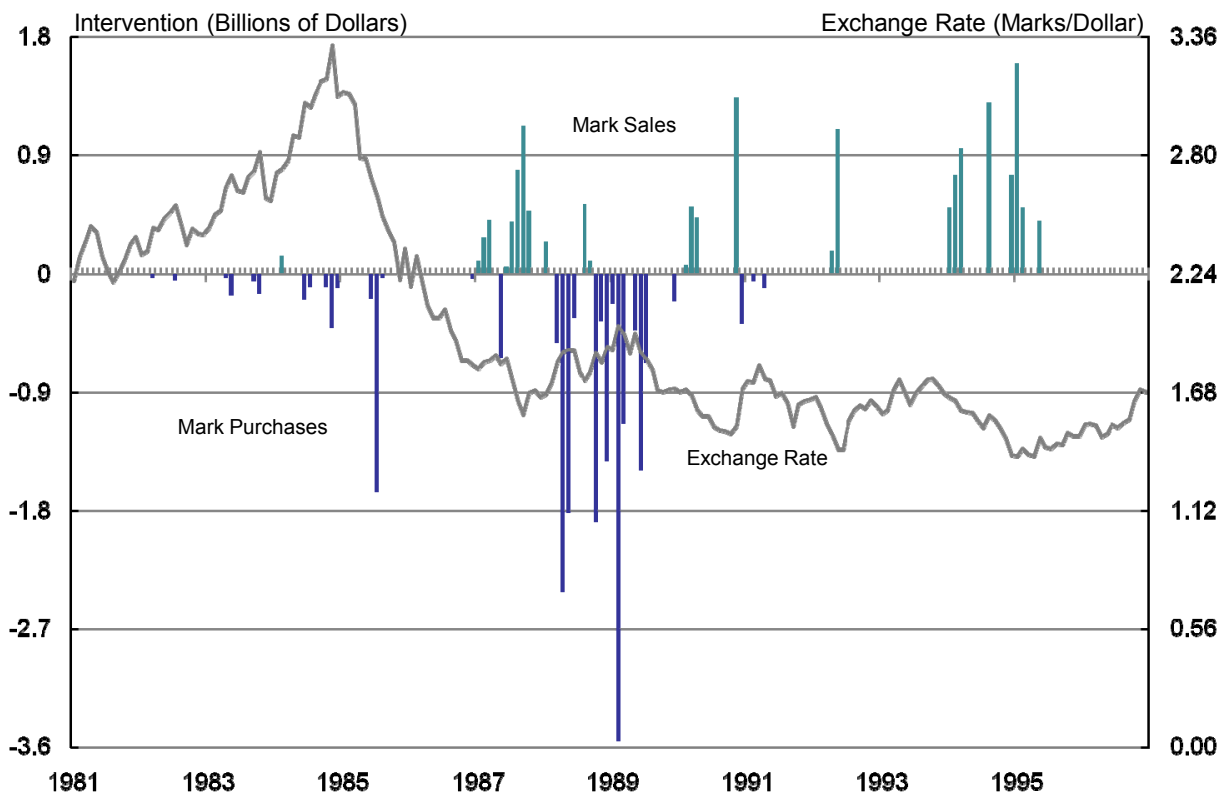

Sources: Board of Governors of the Federal Reserve System; Federal Reserve Bank of New York

Figure 2: U.S. Intervention against Japanese Yen April 1981 - March 1997

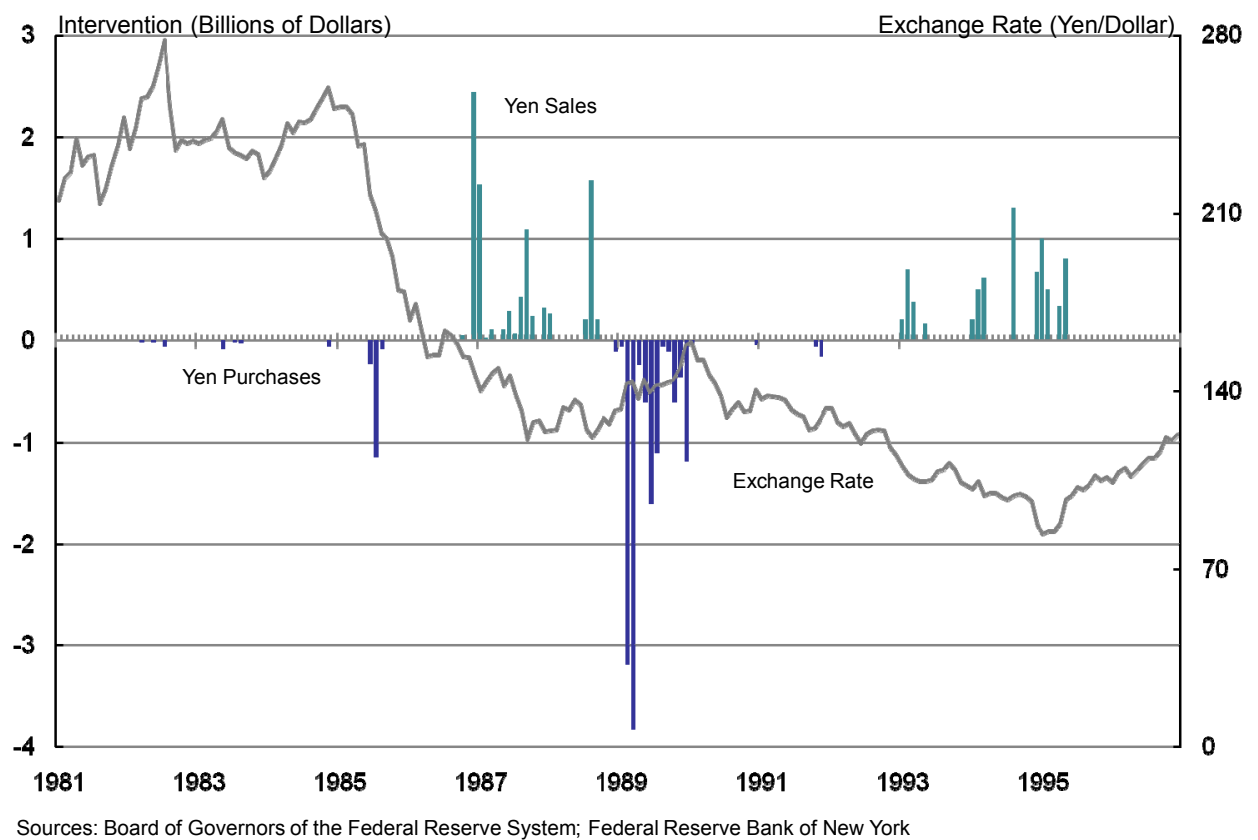


Figure 3: Real Federal Funds Rate

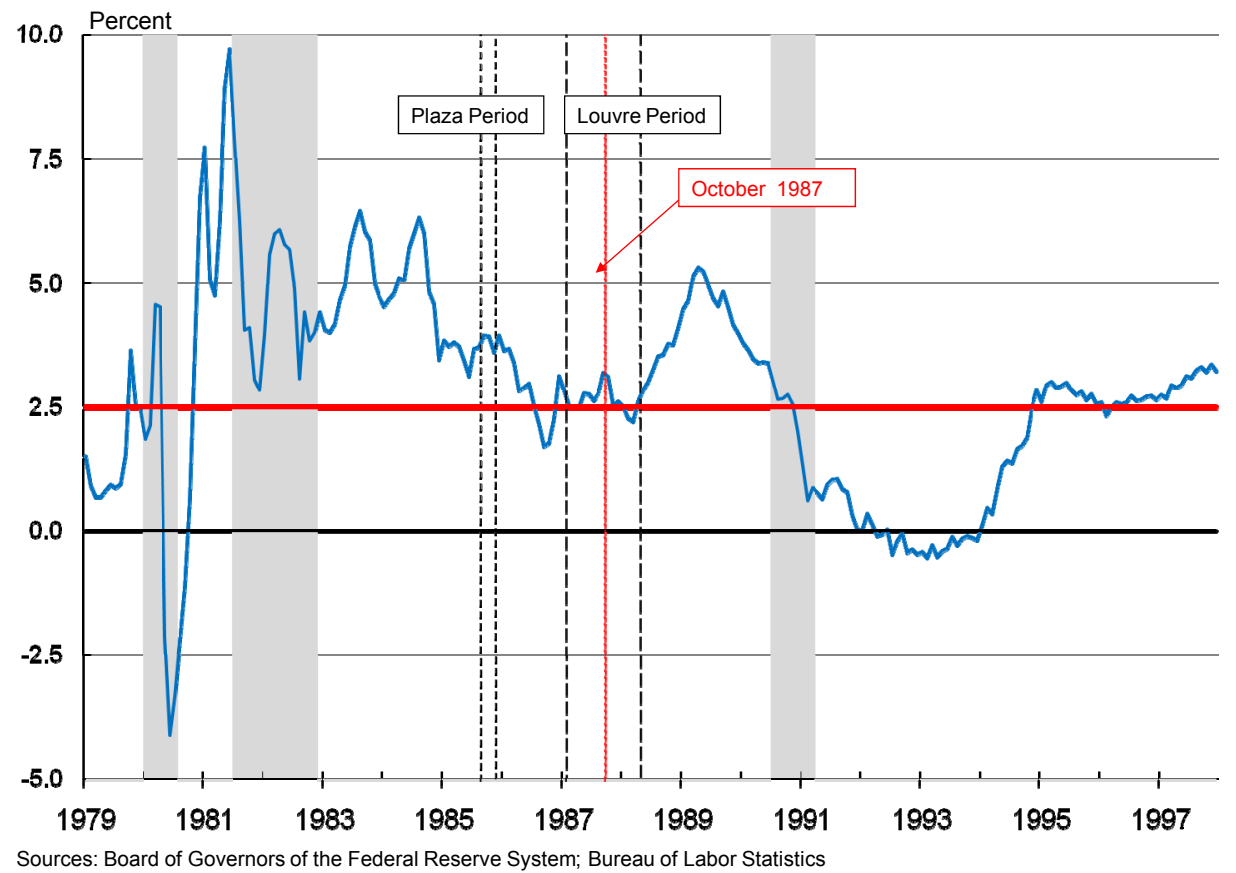

Figure 4: U.S. Policy Rates

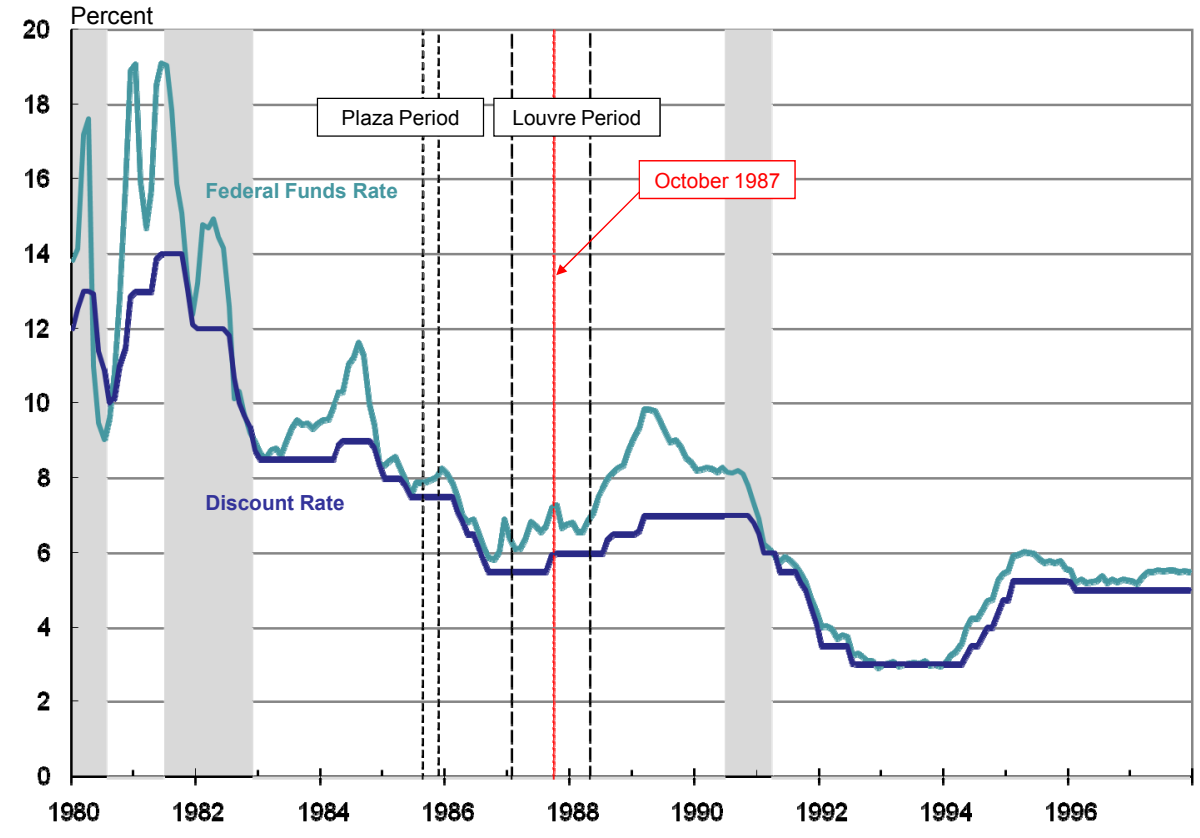

Source: Board of Governors of the Federal Reserve System 
Figure 5: Nominal Short Term Rates

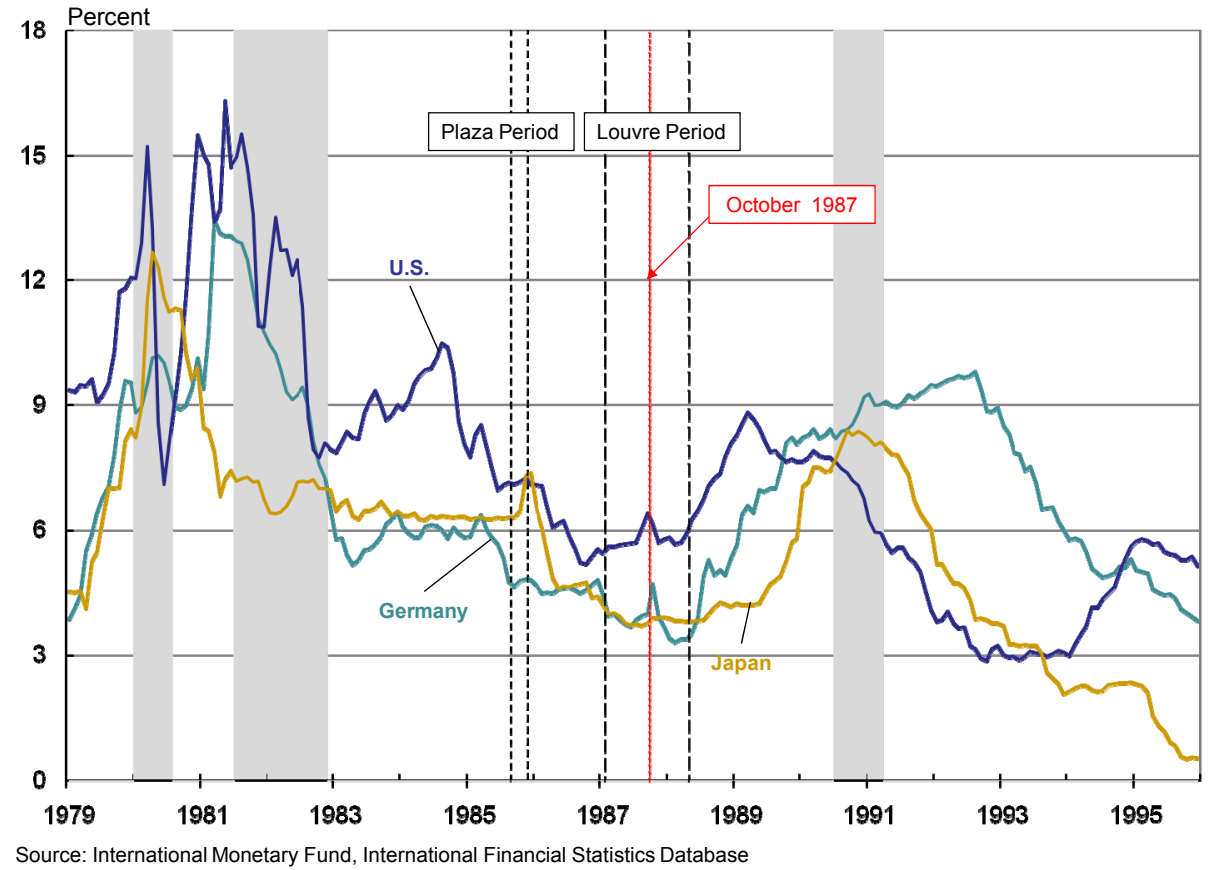

Figure 6: Real Short Term Rates

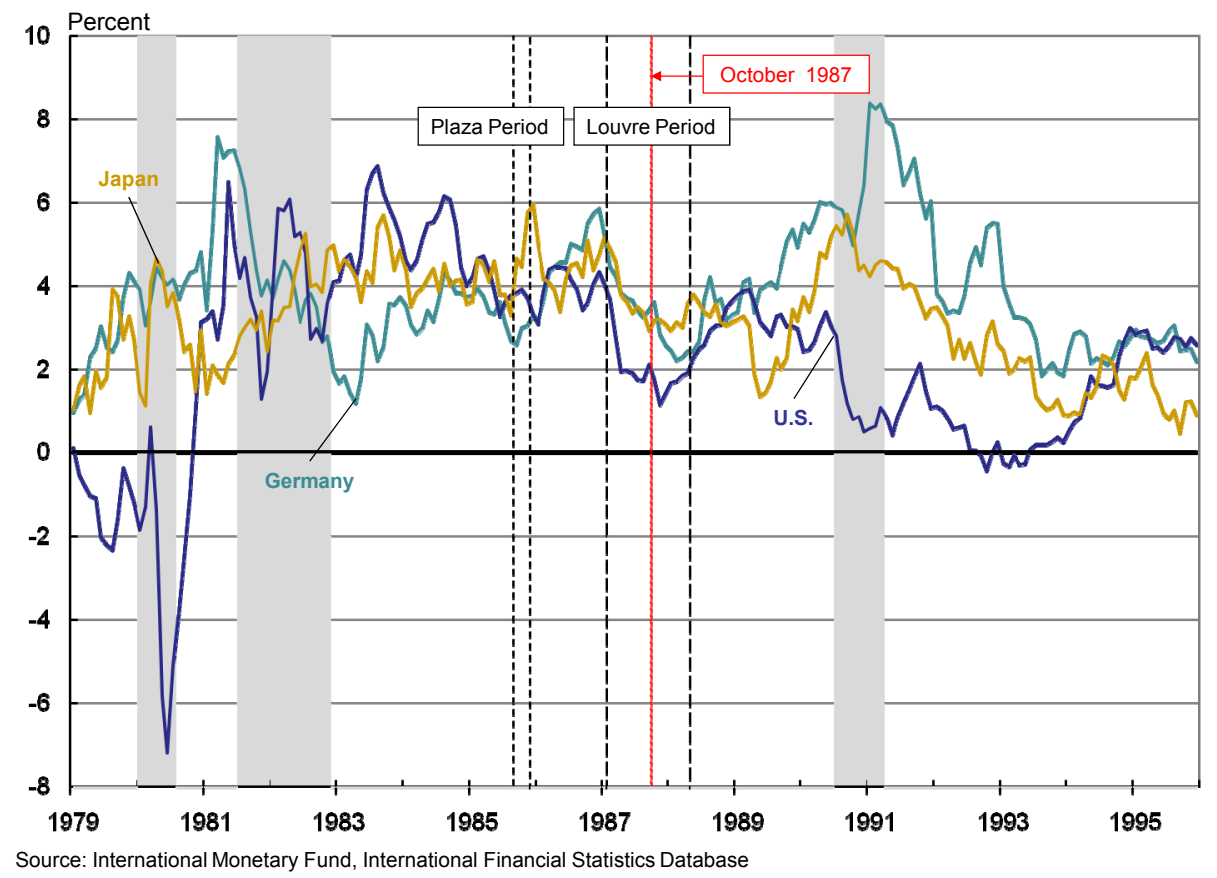


Figure 7: U.S. Intervention against German Marks, 16 September 1985 - 6 November 1985

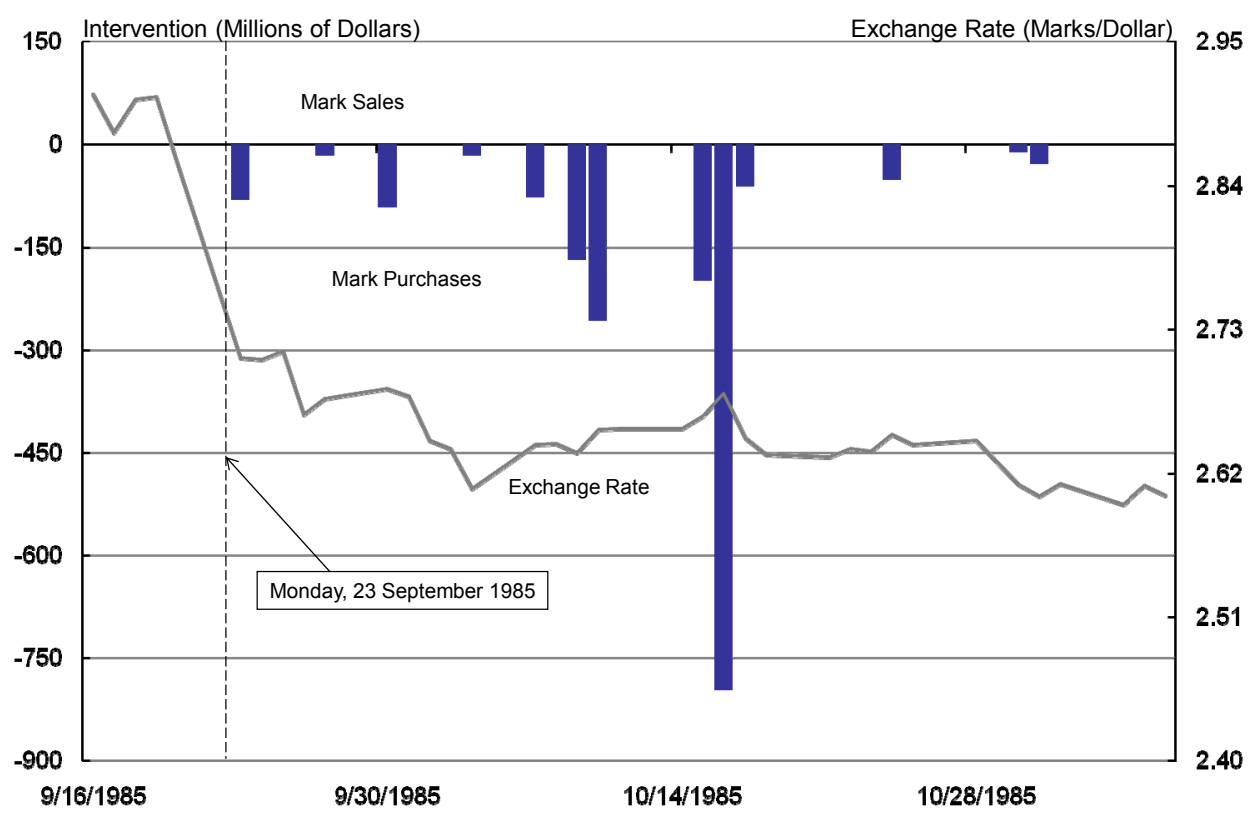

Sources: Board of Governors of the Federal Reserve System; Federal Reserve Bank of New York

Figure 8: U.S. Intervention against Japanese Yen, 16 September 1985 - 6 November 1985

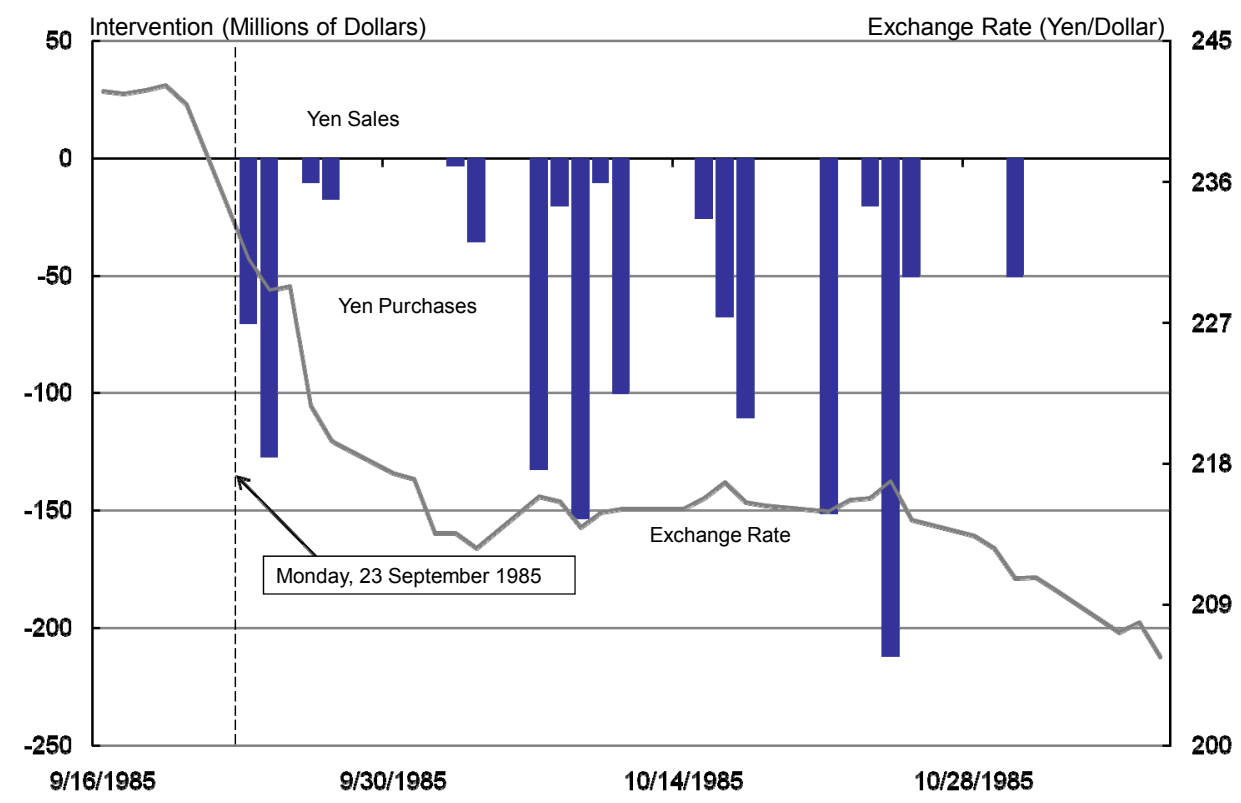

Sources: Board of Governors of the Federal Reserve System; Federal Reserve Bank of New York 
Figure 9: Central Bank Discount Rates

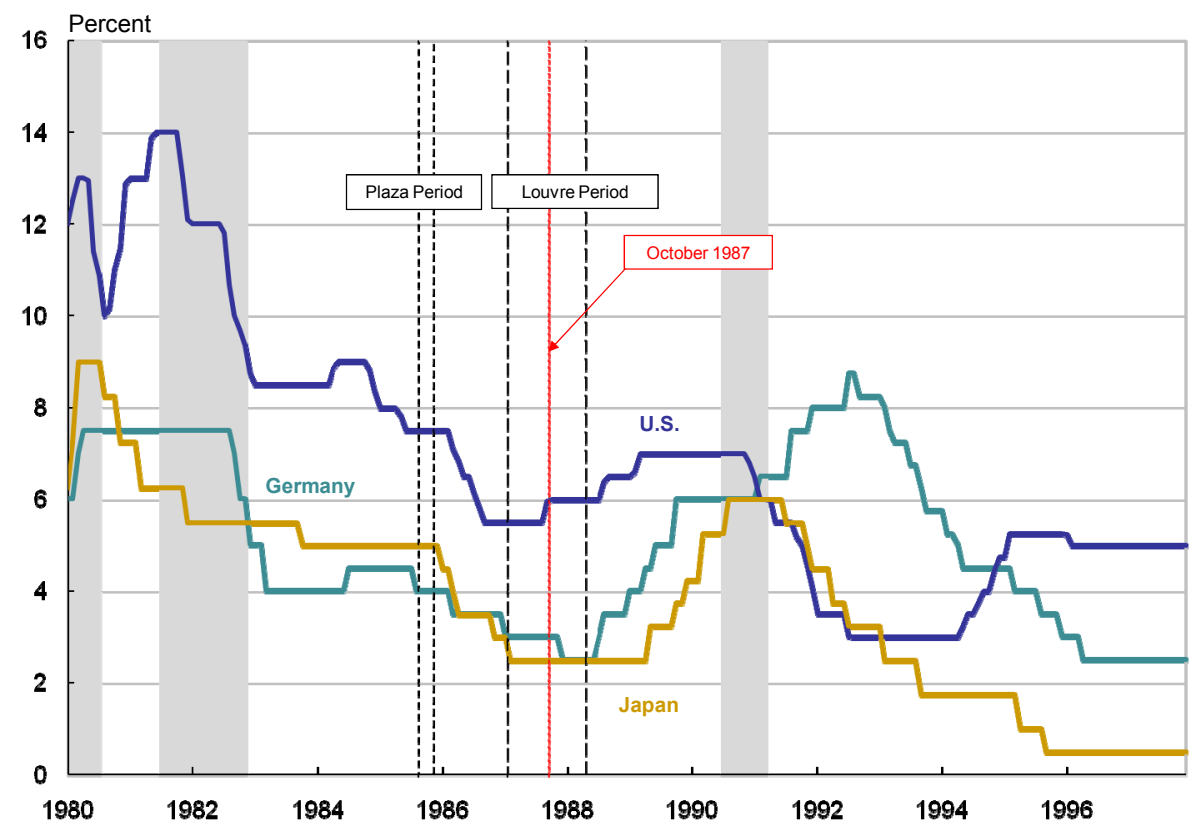

Source: International Monetary Fund, International Financial Statistics Database 
Figure 10: U.S. Intervention against German Marks, March 1987 - April 1988

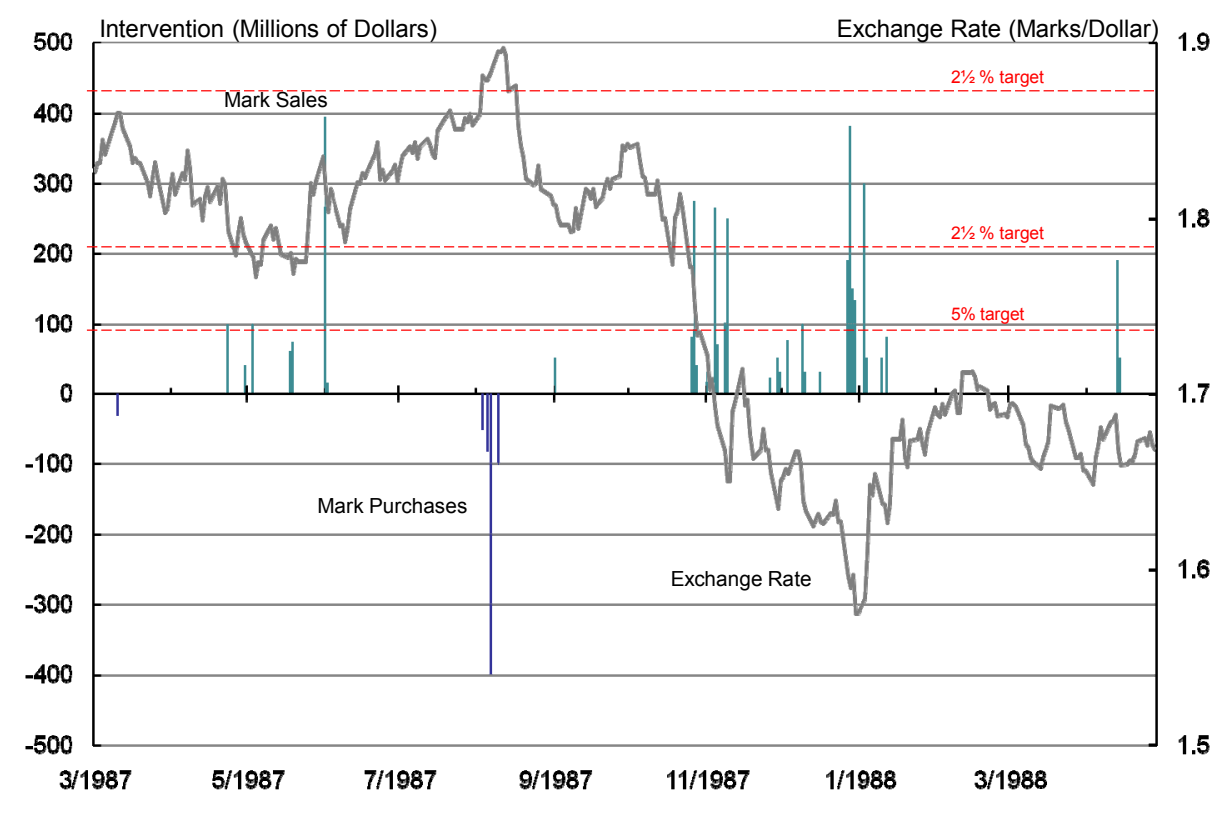

Sources: Board of Governors of the Federal Reserve System; Federal Reserve Bank of New York

Figure 11: U.S. Intervention against Japanese Yen, March 1987 - April 1988

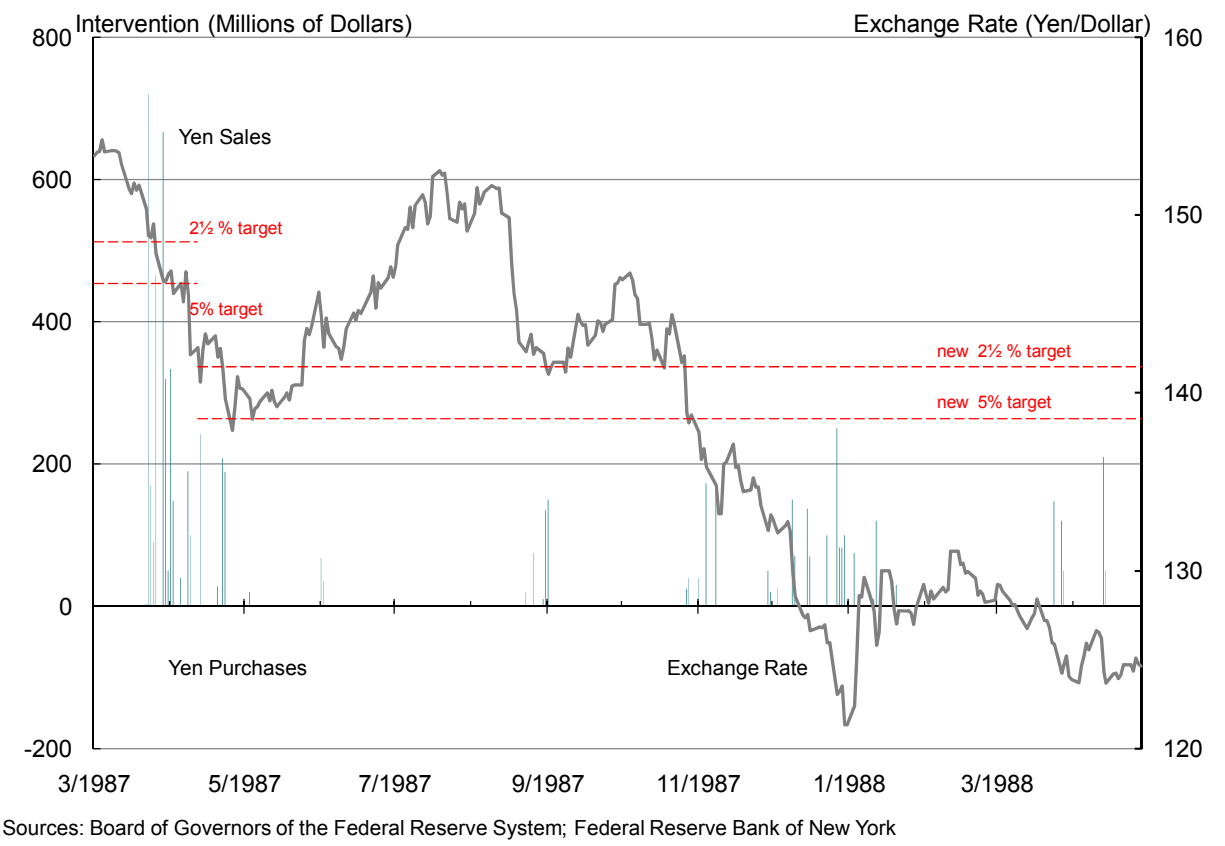


Figure 12: U.S. Foreign Exchange Intervention and the Fed Funds Rate

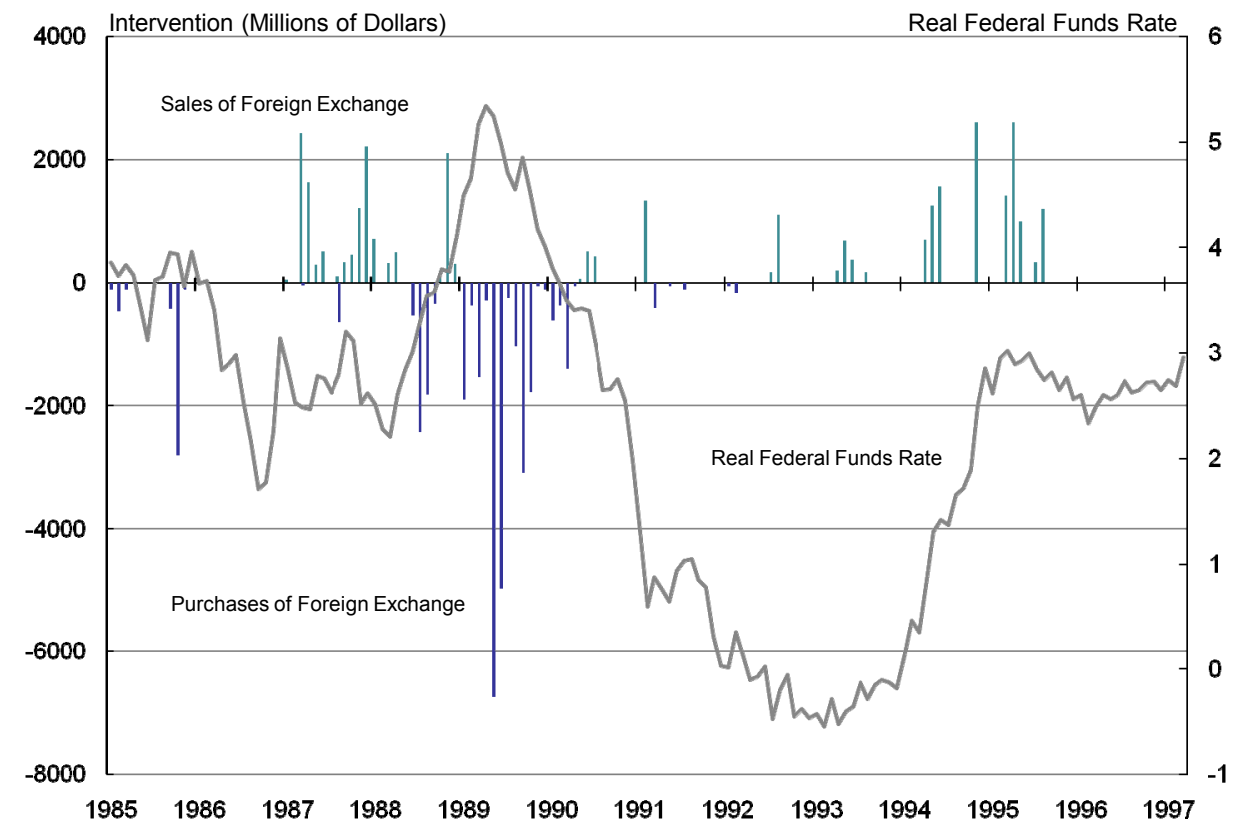

Sources: Board of Governors of the Federal Reserve System; Federal Reserve Bank of New York 
Figure 13: FOMC Authorizations for Net Open Position

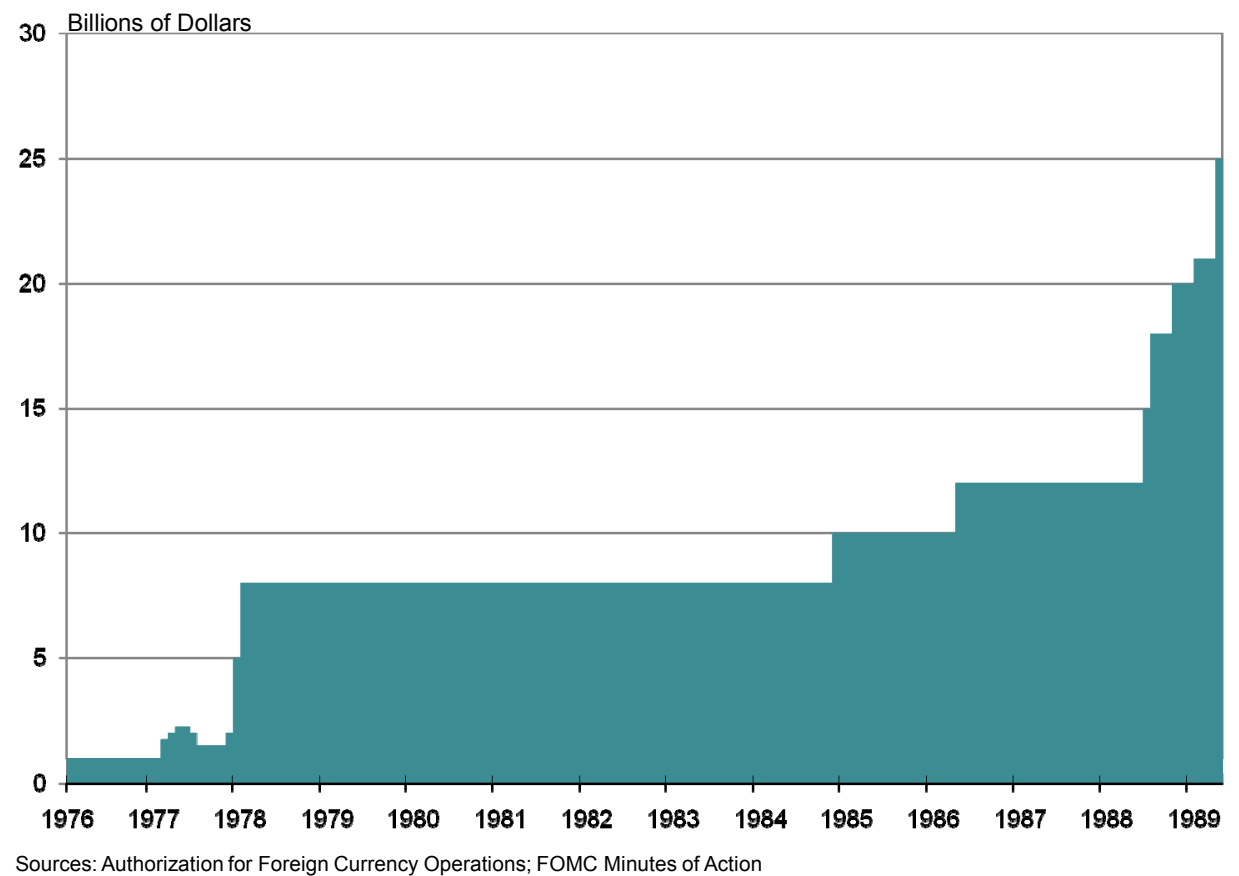

Figure 14: FOMC Authorizations for Warehousing

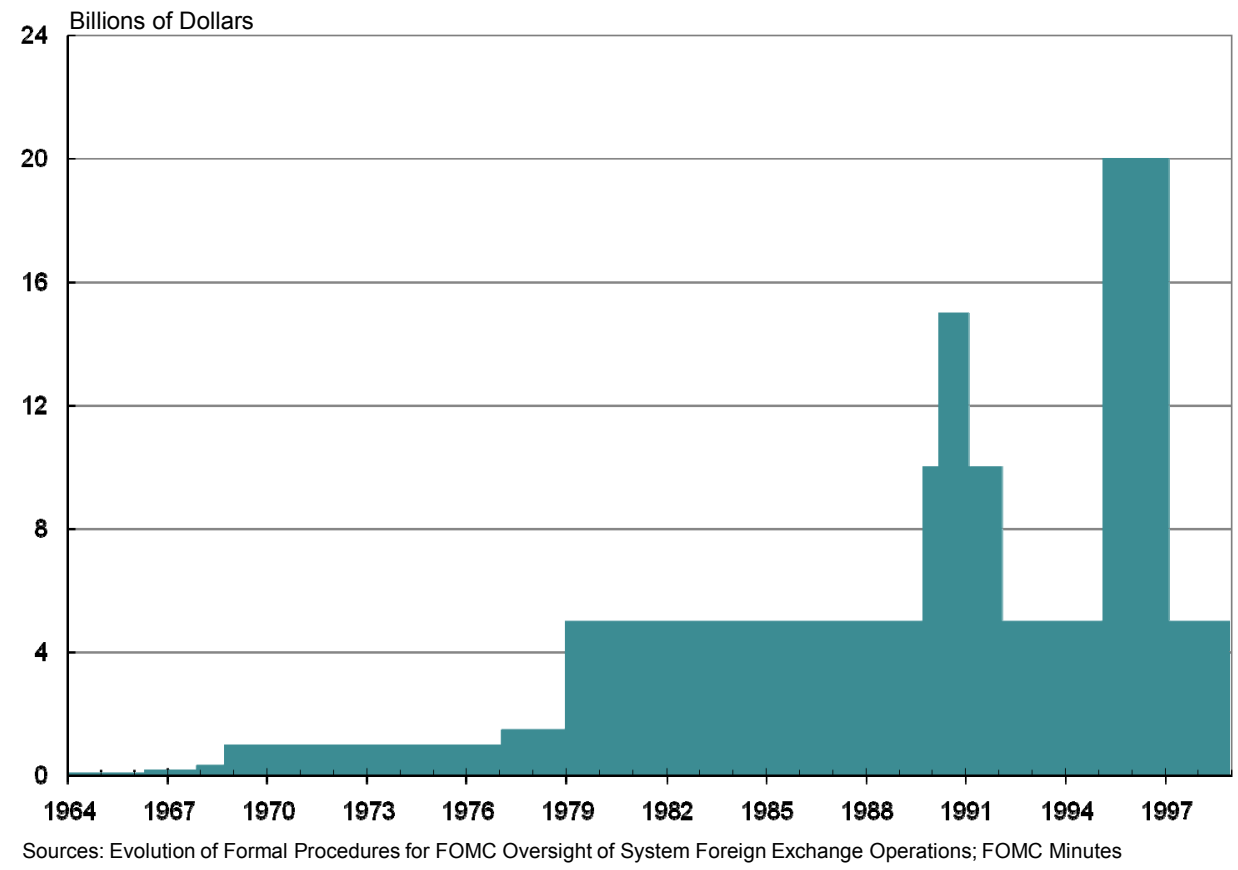


Table 1: Interventions during the Minimalist Period

\section{$\begin{array}{llllll}\text { All } & 1981 & 1982 & 1983 & 1984 & 1985\end{array}$}

$\begin{array}{rcccccc}\text { German marks: } & \mathbf{2 5} & 0 & 4 & 5 & 8 & 8 \\ \text { purchases } & \mathbf{2 4} & 0 & 4 & 5 & 7 & 8 \\ \text { sales } & \mathbf{1} & 0 & 0 & 0 & 1 & 0 \\ & & & & & & \\ \text { Japanese yens: } & \mathbf{1 1} & 0 & 5 & 5 & 0 & 1 \\ \text { purchases } & \mathbf{1 1} & 0 & 5 & 5 & 0 & 1 \\ \text { sales } & \mathbf{0} & 0 & 0 & 0 & 0 & 0\end{array}$

Note: Purchases or sales of foreign currencies against U.S. dollars between 20 April 1981 and 29 March 1985. The Desk bought only Japanese yen on 6 October 1982, 31 October 1983, 1 November 1983. 
TABLE 2: SUCCESS COUNTS FOR U.S. INTERVENTION 20 April 1981 to 29 March 1985 OPENING BID QUOTES

\begin{tabular}{|c|c|c|c|c|c|c|c|}
\hline & TOTAL & $\begin{array}{l}\text { INTERVENTION } \\
\text { SUCCESSES }\end{array}$ & & $\begin{array}{c}\text { VIRTUAL } \\
\text { SUCCESSES }\end{array}$ & & $\begin{array}{l}\text { EXPECTED } \\
\text { SUCCESSES }\end{array}$ & $\begin{array}{l}\text { STANDARD } \\
\text { DEVIATION }\end{array}$ \\
\hline German Marks & \# & \# & $\%$ & \# & $\%$ & \# & \# \\
\hline Observations: & 1030 & & & & & & \\
\hline \multicolumn{8}{|l|}{ Appreciation/Depreciation } \\
\hline sell marks & 1 & 0 & 0.0 & 517 & 50.2 & 1 & 1 \\
\hline buy marks & 24 & 6 & 25.0 & 464 & 45.0 & 11 & 2 \\
\hline total & 25 & 6 & 24.0 & & & & \\
\hline \multicolumn{8}{|l|}{ Moderate Movements } \\
\hline sell marks & 1 & 0 & 0.0 & 118 & 11.5 & 0 & 0 \\
\hline buy marks & 24 & 7 & 29.2 & 146 & 14.2 & 3 & 2 \\
\hline total & 25 & 7 & 28.0 & & & & \\
\hline \multicolumn{8}{|l|}{ Either Criterion } \\
\hline sell marks & 1 & 0 & 0.0 & 635 & 61.7 & 1 & 0 \\
\hline buy marks & 24 & 13 & 54.2 & 610 & 59.2 & 14 & 2 \\
\hline total & 25 & 13 & 52.0 & & & & \\
\hline
\end{tabular}

Japanese Yen

Observations: 1030

Appreciation/Depreciation

sell yen 0

buy yen 11

total 11

Moderate Movements

$\begin{array}{cc}\text { sell yen } & 0 \\ \text { buy yen } & 11 \\ \text { total } & 11 \\ & \end{array}$

Either Criterion

$\begin{array}{rc}\text { sell yen } & 0 \\ \text { buy yen } & 11 \\ \text { total } & 11\end{array}$

0

4

4

0

5

5

0

9

9 na

36.4

36.4

na

45.5

45.5

na

81.8

81.8
449

50.4

43.6

102

142

9.9

13.8

0

2

0

1

621

591
60.3

57.4
0

2 
TABLE 3: SUCCESS COUNTS FOR U.S. INTERVENTION 1 April 1985 to 29 April 1988

OPENING BID QUOTES

\begin{tabular}{|c|c|c|c|c|c|c|c|}
\hline & TOTAL & $\begin{array}{l}\text { INTERVENTION } \\
\text { SUCCESSES }\end{array}$ & & $\begin{array}{c}\text { VIRTUAL } \\
\text { SUCCESSES }\end{array}$ & & $\begin{array}{l}\text { EXPECTED } \\
\text { SUCCESSES }\end{array}$ & $\begin{array}{l}\text { STANDARD } \\
\text { DEVIATION }\end{array}$ \\
\hline German Marks & \# & \# & $\%$ & \# & $\%$ & \# & \# \\
\hline Observations: & 805 & & & & & & \\
\hline \multicolumn{8}{|l|}{ Appreciation/Depreciation } \\
\hline sell marks & 33 & 11 & 33.3 & 349 & 43.4 & 14 & 3 \\
\hline buy marks & 19 & 8 & 42.1 & 421 & 52.3 & 10 & 2 \\
\hline total & 52 & 19 & 36.5 & & & & \\
\hline \multicolumn{8}{|l|}{ Moderate Movements } \\
\hline sell marks & 33 & 11 & 33.3 & 132 & 16.4 & 5 & 2 \\
\hline buy marks & 19 & 4 & 21.1 & 80 & 9.9 & 2 & 1 \\
\hline total & 52 & 15 & 28.8 & & & & \\
\hline \multicolumn{8}{|l|}{ Either Criterion } \\
\hline sell marks & 33 & 22 & 66.7 & 481 & 59.8 & 20 & 3 \\
\hline buy marks & 19 & 12 & 63.2 & 501 & 62.2 & 12 & 2 \\
\hline total & 52 & 34 & 65.4 & & & & \\
\hline
\end{tabular}

Japanese Yen

Observations: $\quad 805$

Appreciation/Depreciation

sell yen $\quad 52$

buy yen 20

total 72

Moderate Movements

$\begin{array}{rr}\text { sell yen } & 52 \\ \text { buy yen } & 20 \\ \text { total } & 72\end{array}$

Either Criterion

$\begin{array}{rr}\text { sell yen } & 52 \\ \text { buy yen } & 20 \\ \text { total } & 72\end{array}$

25

10

35

10

2

12

35

12

47
48.1

50.0

48.6

19.2

10.0

16.7

67.3

60.0

65.3
349

412

43.4

51.2

23

10

3

2

111

84

13.8

10.4

7

2

2

1

35

2

7

460

496

57.1

61.6

30

12
3

2 
TABLE 4: SUCCESS COUNTS FOR U.S. INTERVENTION 2 May 1988 to 19 March 1997

OPENING BID QUOTES

German Marks

\section{Observations: 2318}

Appreciation/Depreciation

$$
\text { sell marks } 44
$$

buy marks 111

total 155

Moderate Movements

$$
\begin{array}{rc}
\text { sell marks } & 44 \\
\text { buy marks } & 111 \\
\text { total } & 155
\end{array}
$$

Either Criterion

$\begin{array}{rc}\text { sell marks } & 44 \\ \text { buy marks } & 111 \\ \text { total } & 155\end{array}$

\section{Japanese Yen}

Observations: 2317

Appreciation/Depreciation

$$
\text { sell yen } 31
$$

buy yen 87

total 118

Moderate Movements

$\begin{array}{rc}\text { sell yen } & 31 \\ \text { buy yen } & 87 \\ \text { total } & 118\end{array}$

Either Criterion

$$
\begin{array}{rc}
\text { sell yen } & 31 \\
\text { buy yen } & 87 \\
\text { total } & 118
\end{array}
$$

INTERVENTION

SUCCESSES

$$
\text { \# }
$$

22

54

76

6

17

23

28

71

99
VIRTUAL SUCCESSES

\#

1121

1100

48.6

49.0

13.6

15.3

14.8

63.6

64.0

63.9

274

305

1395

1405
EXPECTED SUCCESSES

\#

48.4

47.5

11.8

13.2

5

15

2

3

60.2

60.6

26

67

3

5

48.4

1156

49.9

15

3

43.7

1064

45.9

40

5

53

44.9

25.8

272

11.7

4

2

16.1

13.2

11

3

22

18.6

$74.2 \quad 1428$

61.6

19

3

59.8

1369

59.1

51

5 


\section{REFERENCES}

\section{Abbreviations use in text for references:}

BIS: Bank for International Settlements

Bulletin: Treasury and Federal Reserve Foreign Exchange Operations, or Treasury and Federal Reserve Foreign Exchange Operations: Interim Report.

CEA: Council of Economic Advisors

Desk Report: Federal Reserve Bank of New York, Annual Report on Operations in Foreign Currencies

FOMC Minutes: Minutes of the Federal Open Market Committee. FOMC Transcripts: Transcripts of Federal Open Market Committee. NYT: New York Times

Adams D. and Henderson, D. 1983. Definition and Measurment of Exchange Market Intervention. Board of Governors of the Federal Reserve System, Staff Studies No. 126.

Bank for International Settlements. 1983. Fifty-Third Annual Report, $1^{\text {st }}$ April 1982-31 ${ }^{\text {st }}$ March 1983, Basle.

Bagshaw, Michael and Humpage, Owen. 1986. Intervention, Exchange-Rate Volatility, and the Stable Paretian Distribution. Federal Reserve Bank of Cleveland Working Paper 8608. (July).

Bonser-Neal, C., Roley, V. V. and Sellon, G. H. Jr. 1998. Monetary Policy Actions, Intervention, and Exchange Rates: A Reexamination of the Empirical Relationships Using Federal Funds Rate Target Data. Journal of Business, 71 (2):147-177.

Bordo, Michael D. and Schwartz, Anna J. 1991. What Has Foreign Exchange Market Intervention Since the Plaza Agreement Accomplished? Open Economies Review 2 (1):39-64.

Broaddus, J. Alfred and Goodfriend, Marvin. 1996. Foreign Exchange Operations and the Federal Reserve. Federal Reserve Bank of Richmond Economic Quarterly 82 (1):1-20.

Carlson, Mark. 2006. A Brief History of the 1987 Stock Market Crash with a Discussion of the Federal Reserve Response. Board of Governors of the Federal Reserve System, Finance and Economics Discussion Series 2007-13 (November).

Cross, Sam Y. 1985-86. Treasury and Federal Reserve Foreign Exchange Operations, AugustOctober 1985, Interim Report. Federal Reserve Bank of New York Quarterly Review (Winter):45-48.

Cross, Sam Y. (1987) Treasury and Federal Reserve Foreign Exchange Operations, AugustOctober 1985, Interim Report. Federal Reserve Bank of New York Quarterly Review (Spring):45-48.

Cross, Sam Y. and Truman, Edwin M. 1990. Task Force on System Foreign Currency Operations. Memorandum to the Federal Open Market Committee, (9 March). 
Council of Economic Advisors (1984) Economic Report of the President. Transmitted to Congress February 1984, Washington D.C.: Government Printing Office.

Destler, I.M. and Henning, C Randall. 1989. Dollar Politics: Exchange Rate Policymaking in the United States. Washington, D.C.: Institute for International Economics.

Dobson, Wendy. Economic Policy Coordination: Requiem of First Step? Policy Analysis in International Economics No. 30. Washington, D.C.: Institute for International Economics, May 1991.

Dominguez, K. M. 1992. The Informational Role of Official Foreign Exchange Intervention Operations: The Signaling Hypothesis. In: Dominguez, K. M. (Ed.) Exchange Rate Efficiency and the Behavior of International Asset Markets. New York: Garland Publishing Company, pp. 41-80.

Dornbusch, Rudiger. 1976. Expectations and Exchange Rate Dynamics. Journal of Political Economics 84(6):1161-76.

Edison, H. 1993. The Effectiveness of Central Bank Intervention: A Survey of the Literature after 1982. Princeton University, Special Papers in International Economics, No. 18.

Federal Reserve Bank of Kansas City 1985. The U.S. Dollar-Recent Developments, Outlook, and Policy Options. A Symposium Sponsored by the Federal Reserve Bank of Kansas City, Jackson Hole, Wyoming August 21-23.

Federal Reserve Bank of New York, Annual Report on Operations in Foreign Currencies, unpublished report submitted by the Special Manager of the System Open Market Account for Foreign Currency Operations to the Federal Open Market Committee, various issues.

Feldstein, Martin. 1986. New Evidence on the Effects of Exchange Rate Interventions, NBER Working Paper No. 2052 (October).

Feldstein, Martin. 1994. American Economic Policy in the 1980s: A Personal View. in Martin Feldstein (ed.) American Economic Policy in the 1980s, Chicago: University of Chicago Press.

Frankel, Jeffrey. 1994. Exchange Rate Policy. in Martin Feldstein (ed.) American Economic Policy in the 1980s, Chicago: The University of Chicago Press.

Frankel, Jeffrey and Rockett, Katharine E. 1988. International Macroeconomic Policy Coordination When Policymakers Do Not Agree on the True Model. American Economic Review 78 (3):318-40.

Funabashi, Yoichi. Managing the Dollar: From the Plaza to the Louvre, Washington, D.C.: Institute for International Economics, 1988.

Genberg, Hans 1981. On the Effects of Central Bank Intervention in the Foreign Exchange Market. Unpublished paper of the International Monetary Fund Research Department, 8 April 1981.

Goodfriend, Marvin. 1994 Why We Need an 'Accord' for Federal Reserve Credit Policy: A Note. Journal of Money, Credit, and Banking 26 (3):572-580. 
Ghosh, Atish R. and Masson, Paul R. 1988. International Policy Coordination in a World with Model Uncertainty. International Monetary Fund Staff Papers, 35 (2):230-58.

Hagen, Jurgen von. 1989. Monetary Targeting with Exchange Rate Constraints: The Bundesbank in the 1980s. Federal Reserve Bank of St. Louis Review, September/October 53-69.

Hamada, Koichi and Masahiro Kawai. 1997. International Economic Policy Coordination: Theory and Policy Implications. in Michele U. Fratianni, Dominick Salvatore, and Jürgen von Hagen (eds.) Macroeconomic Policy in Open Economies Westport, Conn: Greenwood Press.

Henderson, Dale and Sampson, Stephanie. 1983. Intervention in Foreign Exchange Markets, A Summary of Ten Staff Studies. Federal Reserve Bulletin 69 (11):830-836.

Hetzel, Robert L. 2002. German Monetary History in the Second Half of the Twentieth Century: From the Deutsche Mark to the Euro. Federal Reserve Bank of Richmond Economic Quarterly, 88 (2):29-64.

Hetzel, Robert L. (2008) The Monetary Policy of the Federal Reserve, A History. New York: Cambridge University Press.

Holthan, Gerald and Hallet, Andrew Hughes. 1987. International Policy Cooperation and Model Uncertainty. in Ralph C. Bryant and Richard Portes (eds.) Global Macroeconomics: Policy Conflict and Cooperation. New York: St. Martin's Press 128-77.

Humpage, Owen F. 1984. Dollar Intervention and the Deutchemark-Dollar Exchange Rate Federal Reserve Bank of Cleveland Working Papers 8404.

Humpage, Owen F. 1988. Intervention and the Dollar's Decline Federal Reserve Bank of Cleveland Economic Review 24(2):2-16.

Humpage, Owen F. 1990. A Hitchhiker's Guide to International Macroeconomic Policy Coordination. Federal Reserve Bank of Cleveland Economic Review 26 (1):1- 14.

Humpage, Owen F. 1991. Central-Bank Intervention: Recent Literature, Continuing Controversy. Federal Reserve Bank of Cleveland Economic Review 27(2):13-26.

Hutchinson, M. 1984. Intervention, Deficit Finance and Real Exchange Rates: The Case of Japan. Federal Reserve Bank of San Francisco. Economic Review, Winter: 27-44.

Jurgensen, P. (Chairman) 1983. Report of the Working Group on Exchange Market Intervention. Washington D.C.: U.S. Treasury Department (March).

Kahn, George A. and Jacobson, Kristina 1989. Lessons from West German Monetary Policy. Federal Reserve Bank of Kansas City Economic Review 74 (4):18-35.

Kaminsky, G. L. and Lewis, K. K. 1996. Does Foreign Exchange Intervention Signal Future Monetary Policy? Journal of Monetary Economics, 37:285-312.

Klein, Michael W. and Rosengren, Eric. 1991. Foreign Exchange Intervention as a Signal of Monetary Policy. Federal Reserve Bank of Boston New England Economic Review, May/June.

Kole, Linda S. and Meade, Ellen E. 1995. German Monetary Targeting: A Retrospective View. Federal Reserve Bulletin October. 
Loopesko, B. 1984. Relationships Among Exchange Rates, Intervention and Interest Rates: An Empirical Investigation. Journal of International Money and Finance, 3:257-277.

Maroni, Yves 1994a. Mexican Exchange Rate Policy over the Past Forty Years. unpublished memorandum, 10 March.

Maroni, Yves 1994b. History of the Reciprocal Currency ("Swap") Agreement between the Bank of Mexico and the Federal Reserve System. unpublished memorandum, 11 March.

McKibbin, Warwick J. 1997. Empirical Evidence on International Economic Policy Coordination. in Michele U. Fratianni, Dominick Salvatore, and Jürgen von Hagen (eds.) Macroeconomic Policy in Open Economies Westport, Conn: Greenwood Press.

Minutes of the Federal Open Market Committee, Washington, D. C.: Board of Governors of the Federal Reserve System. (unpublished) 29-30 March 1982.

Meese, Richard and Rogoff, Kenneth 1981. Empirical Exchange Rate Models of the Seventies: Are Any Fit to Survive. Board of Governors of the Federal Reserve System International Finance Discussion Papers No. 184, (June).

Meese, Richard and Rogoff, Kenneth 1982. The Out-of-Sample Failure of Empirical Exchange Rate Models: Sampling Error or Misspecification? Board of Governors of the Federal Reserve System International Finance Discussion Papers No. 204, (March).

Meese, Richard and Rogoff, Kenneth 1983. Empirical Exchange Rate Models of the Seventies: Do They Fit Out of Sample. Journal of International Economics, 14(1-2):3-24.

Micossi, S. and Rebecchini, S. 1984. A Case Study on the Effectiveness of Foreign Exchange Intervention. Journal of Banking and Finance 8( ):535-555.

Mussa, M. 1981. The Role of Official Intervention. Occasional Paper No. 6. New York: Group of Thirty.

Neumann, Manfred J.M. and von Hagen, Jurgen. 1991. Monetary Policy in Germany. in Michele Fratianni and Dominik Salvatore (eds.) Handbook on Monetary Policy. Westport, Conn: Greenwood Press.

New York Times. 16 October 1987.

Obstfeld, Maurice. 1990. The Effectiveness of Foreign-Exchange Intervention: Recent Experience, 1985-1988. in William H. Branson, et al. (eds) International Policy Coordination and Exchange Rate Fluctuations. Chicago: University of Chicago Press.

Obstfeld, Maurice.1983. Exchange Rates, Inflation, and the Sterilization Problem. European Economic Review 21( ):161-89.

Obstfeld, Maurice and Rogoff, Kenneth (1997) Foundations of International Macroeconomics, MIT Press: Cambridge Mass.

Richardson, J. David. 1994. U.S. Trade Policy in the 1980s: Turns-and Roads Not Taken. in Martin Feldstein (ed.) American Economic Policy in the 1980s, Chicago: University of Chicago Press 627-658

Rogoff, K. 1984. On the Effects of Sterilized Intervention: An Analysis of Weekly Data. Journal of Monetary Economics, 14:133-150. 
Rogoff, Kenneth. 1985. Can International Monetary Policy Cooperation Be Counterproductive? Journal of International Economics 18( ):199-217.

Schreft, Stacey L. 1990. Credit Controls: 1980. Federal Reserve Bank of Richmond Economic Review, November/ December 25-55.

Solomon, Robert. 1983 "Official Intervention in Foreign Exchange Markets: A Survey," unpublished, revised version (March).

Transcripts of Federal Open Market Committee. Washington, D. C.: Board of Governors of the Federal Reserve System, 1-2 February 1982 through 16 December 1997.

Treasury and Federal Reserve Foreign Exchange Operations. Federal Reserve Bulletin, Washington, D. C.: Board of Governors of the Federal Reserve System. various issues.

Treasury and Federal Reserve Foreign Exchange Operations: Interim Report. Federal Reserve Bulletin, Washington, D. C.: Board of Governors of the Federal Reserve System. various issues.

Volcker, Paul A. and Gyohten, Toyoo. 1992) Changing Fortunes, The World's Money and the Threat to American Leadership. New York: Times Books. 


\section{End Notes}

1 The Reagan administration seemed to begin its minimalist intervention strategy in late February or early March of 1981. U.S. intervention was very heavy in January 1981, but tapered off in February with a final heavy intervention on 22 February 1981, when President Regan was shot. Treasury Secretary Donald Regan formally announced the new policy on 17 April 1981 (see chapter 5).

${ }^{2}$ Chapter 5 discusses the inauguration of Chairman Volcker's monetary-policy initiatives.

3 The FOMC adopted monetary targets in 1970 and began making these targets public in early 1975.

4 In October 1982, the FOMC formally abandoned monetary targets for a federal funds rate target.

${ }^{5}$ During most of the Reagan years, the Republican Party maintained a small majority in the U.S. Senate, but the Democrats had a substantially larger majority in the House of Representatives.

6 "Although I accept that that [a higher real return on investment] could in principle help explain the dollar's strength, my judgment was that the magnitude of the decline in national saving was substantially greater than the increased demand for investment." (Feldstein 1994, p. 67)

7 As chapter 4 explains, Sprinkel contended that because sterilized intervention did not alter fundamental macroeconomic determinants of exchange rates, it could exert only a temporary influence on the market at best. He also maintained that intervention - even when sterilizedcould interfere with domestic monetary policy.

8 This was the most enduring conclusion from the Report. As we will show, FOMC participants referred to it, often noting that to be effective monetary policy had to back up intervention. The Desk and the Treasury seemed to forget the finding. This conclusion ultimately became the focal point for arguments against intervention within the FOMC.

9 Solomon (1983, pp. 7-8) also discussed this problem.

${ }^{10}$ Rogoff (1984) provides a thorough survey of the empirical tests of the portfolio-balance model, especially of those papers important for the study of foreign-exchange intervention. Rogoff's paper circulated as a memo in early 1983 and was undoubtedly part of the background research for the Jurgensen Report.

11 We consider here only high-frequency empirical studies of the effects of intervention. Empirical studies of intervention profits appear in chapter 1, and early studies of intervention appear in chapter 5. 
12 In 1984, the Treasury removed the withholding tax on interest paid to foreigners, which would have increased foreign demand for U.S. financial assets and would have encouraged a real dollar appreciation.

13 See the collection of papers that appear in: Federal Reserve Bank of Kansas (1985)

14 These congressional inquires eventually produced the Omnibus and Trade Competitiveness Act of 1988, which encouraged the President to pursue macroeconomic-policy coordination and exchange-market intervention and instructed the Treasury Secretary to analyze the exchange-rate policies of other countries for exchange-rate manipulation.

15 These interventions were not the only interventions during the minimalist, or pre-Plaza period, but the intervention that began in January 1985 marked a change in the administration's attitudes towards intervention. An analysis of all pre-Plaza interventions follows in the next section.

16 We do not know the exact day of this intervention because it does not appear in the Board's official daily data on U.S. foreign exchange operations.

17 Bagshaw and Humpage studied volatility using the moments of a stable-Paritian distribution.

18 The G5 (Group of Five) consisted of France, Germany, Japan, the United Kingdom and the United States. The G6 consisted of the G5 plus Italy. The G7 consisted of the G6 plus Canada.

19 Volcker had this assessment of exchange markets: "I was pretty well convinced by then [August 1985] as a matter of market judgment that the basic direction of the dollar was lower. Certainly, the growth of the U.S. economy seemed to be losing momentum, and if there was to be any change in monetary policy it would likely be toward greater ease and lower interest rates. But the prospects for a lower dollar were not so clear to others and the dollar rebounded." (Volcker and Gyothen, 1992, pp. 242-243).

20 A reprint of the Plaza communiqué can be found in Funabashi (1988, 261-6). The text references paragraph 18 .

21 Volcker and Gyohten (1992, p. 244 ) also indicate that the United States proposed a 10-12 percent appreciation of foreign currencies relative to the dollar.

${ }^{22}$ We are not sure to which market — Singapore, Hong Kong, Tokyo, or all three — the term "Far East" refers.

${ }^{23}$ We assess the impact using our criteria below.

${ }^{24}$ Feldstein (1986) does find a somewhat faster yen depreciation after the Plaza, but attributes to shift in policy rather that the intervention.

25 On 27 January 1987, the United States sold \$50 million equivalent yen to demonstrate cooperation with Japanese authorities who had recently been buying dollars (Bulletin May 1987, 
p. 333). On 11 March 1987, the United States made a unilateral $\$ 30$ million purchase of German marks.

26 Funabashi (1988, pp. 45 -49) and Destler and Henning (1989, pp, 51-52) discuss this episode. These two accounts differ on whether Volcker had worked out an agreement with Pöhl before or after the Board's vote and his threat to resign. The text follows Destler and Henning, which is consistent with Volcker and Gyohten (1992, p. 274).

27 The G6 Communiqué is reprinted in Funabashi (1988, pp. 279-280).

28 Funabashi's book is based on anonymous interviews participants associated with the G5, G6 or G7 meetings.

29 Frankel (1994, p. 307) notes: "Most knowledgeable observers surmised that probably no explicit quantitative range had in fact been agreed on."

30 See also Kahn and Jacobson (1989) and, for a somewhat different opinion, Obstfeld (1983).

31 See Klein and Rosengreen (1991), Dominguez (1992), Kaminsky and Lewis (1996)

32 The Plaza operation consisted only of sales of foreign exchange, mostly German marks, which the System and the Treasury split equally. The Louvre operations consisted mostly of purchases of foreign exchange, although U.S. monetary authorities sometimes sold foreign exchange. The Federal Reserve System financed most of the German mark operations during the Louvre period, while the Treasury financed most of the Japanese yen interventions. On balance, the Treasury spent somewhat more than the Federal Reserve.

33 One of the Jurgensen Report's conclusions maintained that monetary authorities needed to back their sterilized interventions with appropriate monetary policies, if such operations were to have anything other than a fleeting affect on exchange rates.

34 The dollar generally appreciated despite the repeated sales of dollars.

35 The view that intervention increases exchange-rate volatility has considerable empirical support.

${ }^{36}$ Cross discusses discrete intervention as a tactical choice (see Chapter 4). He did not discuss it as a means for avoiding a conflict between monetary policy and intervention.

37 Cross explained discrete intervention: "That is to say, we operated through a bank acting as an agent so they - although the word does get around in some way and people who are following these markets closely can often tell a lot of what's going on-we did not go in openly buying foreign currencies." (FOMC Transcripts 5 \& 6 July 1989, p.3)

38 The page numbers in this paragraph refer to Cross and Truman (9 March 1990). 
39 The Transcripts do not explain how Brady determined this amount. The Board redacted part of the Transcripts. The amount may include foreign intervention amounts against yen. Since 1 January 1989, the United States had purchased \$13 billion equivalent Japanese yen.

40 Congressman Gonzales was currently threatening to hold hearings on the System's portfolio of foreign exchange.

41 This and subsequent Japanese interventions are from published official Japanese Ministry of Finance data, which we converted to dollars at prevailing exchange rates.

42 The article initially appeared in the Federal Reserve Bank of Richmond's 1995 Annual Report.

43 Much of the background on Mexico's swap lines comes from Maroni (1994a,b).

44 Federal Reserve Bank of Richmond President Broaddus dissented.

45 The United States also set up a \$2 billion swap line with Canada.

46 Texas Congressman Henry Gonzalez was highly critical of the swap lines, claiming that Congress never granted the Federal Reserve explicit legal authority for swap lines, and that they exposed U.S. taxpayers to default risk. 